Trinity University

Digital Commons @ Trinity

$5-2020$

\title{
The Impact of Inter-Bed Cohesion on Fold-Related Fracture Development, Stillwell Anticline, West Texas (USA)
}

\section{Benjamin E. Surpless}

Trinity University, bsurples@trinity.edu

S. S. Wigginton

Follow this and additional works at: https://digitalcommons.trinity.edu/geo_faculty

Part of the Earth Sciences Commons

\section{Repository Citation}

Surpless, B., \& Wigginton, S. S. (2020). The impact of inter-bed cohesion on fold-related fracture development, Stillwell Anticline, West Texas (USA). Journal of Structural Geology, 134, Article 103974. http://doi.org/10.1016/j.jsg.2019.103974

This Post-Print is brought to you for free and open access by the Geosciences Department at Digital Commons @ Trinity. It has been accepted for inclusion in Geosciences Faculty Research by an authorized administrator of Digital Commons@ Trinity. For more information, please contact jcostanz@trinity.edu. 
Title:

The impact of inter-bed cohesion on fold-related fracture development, Stillwell anticline, west Texas (USA)

\section{Acknowledgements}

Most of this work was funded by a grant from the National Science Foundation (EAR-PUI grant 1220235), with portions of fieldwork, transportation, student support, and laboratory analyses funded by the Trinity University Department of Geosciences. We are grateful for the insightful review of an early version of this manuscript by Vincent Heesakkers, Wayne Narr, and Chris Zahm, and we are grateful to two anonymous reviewers of this manuscript. These reviews greatly improved the quality of this article. Thanks also to Rebecca Schauer, Cara Beasley, Luciana de la Rocha, Nicola Hill, Daniel Hoin, Brett Mays, Lauren Mercado, Mark Mlella, Nathan Tinker, and Kristine Quiroz Purcell - Trinity University undergraduates who assisted in field investigations and subsequent analyses. Special thanks to all of the staff at the Black Gap Wildlife Management Area, Brewster County, Texas, including Travis Smith, Dewey Stockbridge, Mike Pittman, and Mark Garrett. Thanks also to Ron Hermann for granting access to his ranch during our research and to Tony Perez and Denise Wilson, Trinity University Department of Geosciences, who aided in the planning and execution of fieldwork. 


\section{Abstract}

The interpretation of fracture networks in contractional folds is challenging due to the range of factors that control fracture formation. We use outcrop-based analysis of fractures in plan-view pavements and in a 9-bed cross-sectional exposure to evaluate the fracture system within Cretaceous limestone layers of a Laramide fold in west Texas, the Stillwell anticline. Openingmode extension fractures (veins) at high angles to bedding dominate the fracture population, although shear fractures and faults cut bedding at low angles within the forelimb. Analysis of extension fractures reveals NW-striking axial parallel and NE-striking axial-perpendicular fracture sets interpreted to have formed during contractional folding, a third $\mathrm{N}$-striking fracture set formed during subsequent Basin and Range extension, and a fourth ESE-striking fracture formed due to unloading during exhumation. Fracture fill textures suggest that many fracture apertures increased during exhumation.

The relative abundances of the four fracture sets and the intensity of each set vary from bed to bed in cross section. Because beds display no significant differences in mechanical strength and there is no correlation between bed thickness and fracture intensity, we attribute this bed-tobed variability to differences in cohesion between beds. Bed decoupling, when combined with low extensional $(<0.5 \%)$ strains, helps explain low vertical persistence. We hypothesize that weak bed cohesion results in variability of fracture patterns within planar fold limbs. In fold limbs with low fracture-related strains, we propose that high angles between fracture sets increases the likelihood of high bed-parallel fracture connectivity, and low fracture vertical persistence results in low vertical connectivity. 


\section{Introduction}

Fractures within contractional anticlines are often interpreted to have formed during fold development, and fracture orientations may be directly related to structural position (e.g., Price, 1966; Friedman, 1969; Stearns and Friedman, 1972; Price and Cosgrove, 1990), with the highest fracture intensities documented where present-day bed curvatures are highest (e.g., Fischer and Wilkerson, 2000; Bergbauer and Pollard, 2004). However, studies have demonstrated that fracture networks with substantial opening-mode growth may develop at low strains even where bedding displays little or no curvature (e.g., Schechter et al., 1996; Olson et al., 2009). Thus, planar limbs of anticlines with little or no curvature may exhibit fracturing that might enhance fluid flow, especially where multiple fracture sets accommodate strain, improving fracture network connectivity (e.g., Odling, 1992; Odling et al., 1999; Ghosh and Mitra, 2009). In this study, we investigate how fracture attributes vary in the planar limbs of the well-exposed Laramide-age Stillwell anticline, west Texas (USA) (Fig. 1), and develop a model to explain the evolution of fracture networks in similar fold systems.

Factors unrelated to folding that can also affect fracture development within a layered stratigraphy include lithology, bed thickness, mechanical stratigraphy, proximity to faults, preexisting fractures, and the presence or absence of interlayer slip (e.g., Price, 1959; Stearns, 1968; Ladeira and Price, 1981; Couples and Lewis, 1998; Nelson, 2001; Underwood et al., 2003; Bergbauer and Pollard, 2004; Ferrill et al., 2007; Smart et al., 2009; Zahm and Hennings, 2009; McGinnis et al., 2015; 2017). In addition, layered strata may exhibit fractures with a range in vertical persistence, from short, bed-bound fractures at high angles to bedding to through- 
going taller fractures that permit better vertical network connectivity (e.g., Gross and Eyal, 2007; Hooker et al., 2013).

The small scale of the Stillwell anticline (10-km long, 550-m wide), west Texas (USA), the well-described carbonate stratigraphy (e.g., St. John, 1965; 1966; Maxwell et al., 1967; Surpless et al., 2015), the well-constrained fold geometry (Surpless et al., 2015), and excellent bedrock exposure permit us to document present-day fractured pavements on planar limbs across the fold (Figs. 1 and 2). We also document fracture characteristics in a package of thin limestone beds exposed in cross-section within the relatively planar middle limb of the Stillwell anticline (Fig. 2), which has experienced low finite strain (Surpless et al., 2015). There, we document fracture orientation, intensity, aperture, vertical persistence, and total strain in the context of lithology, bed thickness, and bed-interface properties. Data are then integrated from both scales to develop a model for fracture formation in similar subsurface systems, where workers rely on incomplete data to make important decisions involving groundwater flow, mineral deposit formation, or petroleum flow and storage.

\section{Background}

\subsection{Structural development of the Stillwell anticline}

In the eastern Big Bend region, which includes the Stillwell anticline, Laramide-age (Late Cretaceous to early Paleogene) fold axes and faults most commonly trend northwest (Fig. 1a; e.g., Abritton and Smith, 1957; Muehlberger, 1980; Moustafa, 1988; Lehman, 1991; Turner et al., 2011). Although stresses related to later Basin and Range extension (25 - $2 \mathrm{Ma}$; Turner et al., 2011) have also affected the region, there is no evidence for map-scale post-Laramide-age faults or folds near the Stillwell anticline (e.g., St. John, 1965; 1966; Maxwell et al., 1967; 
Surpless et al., 2015). The limited tectonic history of carbonate layers in the fold makes the locality ideal for studies related to fold-related fracture formation.

The Stillwell anticline is a NW-trending, NE-vergent, asymmetric fold with an axis that displays a plan-view left-stepping, en echelon pattern (Fig. 1b). Exposed fold geometries are best defined by the resistant Cretaceous Santa Elena Limestone, which was deposited in a neritic, shallow reef environment (St. John, 1965; Moustafa, 1988; Surpless et al., 2015). Axisperpendicular drainages cut through the limestone layers in many locations, providing excellent views of the folded layers (Fig. 2).

Surpless et al. (2015) used field observations, geologic data, cross-sections, and kinematic modeling to establish a two-stage model of contractional fold formation. The first contractional deformation was accommodated by reverse reactivation of a pre-existing, NWstriking, SW-dipping, left-stepping, en echelon normal fault system in Paleozoic basement rocks to generate monoclinal flexures in overlying layered Cretaceous carbonate rocks (Surpless et al., 2015). A subsequent flat-ramp fault system propagated horizontally along the mechanically weak, clay-rich Cretaceous Sue Peaks Formation (which underlies the Cretaceous Santa Elena Limestone) before ramping up at the hinge of the pre-existing monocline (Surpless et al., 2015). The northern segment of the anticline displays a more consistent cross-sectional geometry than the southern segment (Surpless et al., 2015; Figs. 1 and 2), so we focus most fracture observations along the northern segment. However, there are axis-parallel variations in fold geometry related to differences in displacement on the reactivated fault system that cores the anticline (Surpless et al., 2015). 
strain is highest, most shear strain focused along bed interfaces, and limestone beds

accommodate only minor shear strain (Surpless et al., 2015). The relatively planar back and

middle limbs of the anticline display no observable shear strain, but kinematic modeling

predicts low-magnitude shear strain at those structural positions (Surpless et al., 2015).

\subsection{Previous studies of fold-related fractures}

We consider fractures in the context of previous research relating fracture sets to

thrust-related anticline formation (Fig. 2b; e.g., Price, 1966; Muecke and Charlesworth, 1966;

Cooper, 1992; Hanks et al., 1997; Wennberg et al., 2007; Ghosh and Mitra, 2009; Watkins et al.,

2015). These theoretical sets include: 1) a longitudinal fracture set, parallel to the fold axis and at high angles to bedding $\left(\mathrm{J}_{1}\right)$, likely associated with flexure during folding; 2 ) a transverse fracture set, perpendicular to the fold axis $\left(J_{2}\right)$, possibly related to bed curvature associated with plunging of the fold axis; and 3 ) two sets of fractures $\left(S_{1}\right.$ and $\left.S_{2}\right)$, considered conjugate shear fractures, with the $\sigma_{1}$ vector as an acute bisector (e.g., Price, 1966; Watkins et al., 2015).

Fracture sets $S_{1}$ and $S_{2}$ would require fracture formation in a local strike-slip stress regime, with each set at an angle of $30^{\circ}$ from $\sigma_{1}$ and with the $\sigma_{3}$ axis oriented horizontally (e.g., Hancock, 1985), parallel to the fold axis and at high angles to bedding (e.g., Muecke and Charlesworth, 1966; Price, 1966). Researchers have shown that one or more of these 4 sets are commonly absent in fold systems, with local variation in what fracture set or sets are present as well as the intensity of each set (e.g., Hanks et al., 1997; Ghosh and Mitra, 2009; Watkins et al., 2015). 
We used field- and lab-based documentation of fractured pavements on each limb of the Stillwell anticline to establish fracture set orientations, fill characteristics, and chronology on the fold scale (Figs. 1 and 2). Where an arroyo crosscutting the northern segment of the anticline exposes more than 55-m of the upper Santa Elena Limestone, we performed highresolution cross-sectional fracture mapping within a 10-m package of more than 20 resistant limestone beds, well-exposed on the south wall of the canyon (Fig. 2). We combined all structural and spatial data in an integrated GIS database, and we augmented field descriptions and sketches with annotated field photographs.

In this paper, we use the term fracture to represent opening-mode joints, shear fractures, and mixed-mode fractures (with both fracture-perpendicular opening and fractureparallel shear kinematics). We reserve the term fault to represent a fracture that displays fracture-parallel displacement greater than kinematic aperture, consistent with the terminology of McGinnis et al. (2015). We do not use the term vein when a fracture contains mineral fill, but we document fractures as barren, partially filled, or filled where we describe fractures at the pavement or cross-sectional scale. We use the term aperture to represent kinematic aperture, not barren aperture.

Bonnet et al. (2001) point out that any field-based observation of fracture populations is inherently biased by the finite size of the observation domain and the resolution of the given technique used to map fracture patterns. For instance, because studies like ours focus on localities with good exposure, we know that both our field method and our choice of area inevitably bias data from our study. For example, we cannot observe the smallest fractures present, due to a combination of weathering and limitations in the scale of observation. In 
173

addition, we may have chosen a site with set-specific fracture intensities higher or lower than

the true average for one fracture set and higher or lower than the true average fracture intensity for another fracture set (or even absent one or more sets). Finally, when considering a three-dimensional structure like the Stillwell anticline, simply extrapolating from one- or twodimensional data (like the data we present here) to three dimensions introduces uncertainty (Marrett, 1996; Bonnet et al., 2001). We recognize and account for these limitations in our interpretations.

\subsection{Forelimb faulting and fracturing}

In order to document the impact of layering on the three-dimensional accommodation of shear strain through a package of limestone beds, we chose unvegetated outcrops that reveal exposure of bedding both parallel to and perpendicular to the dip of the forelimb. At these locations, we focused on documentation of fault geometries, especially where we could directly observe shear-sense indicators.

\subsection{Fractured pavements and fracture fill characteristics}

Fracture occurrence and orientations were collected on single limestone bed pavements unobscured by vegetation (Figs. 1 and 2). All pavement data are from the upper surfaces of beds within the middle and upper Cretaceous Santa Elena Limestone stratigraphy. Although the approximate stratigraphic position of bedding pavement locations within the Santa Elena Limestone section is known, non-traceability of beds from outcrop to outcrop made it impossible to place pavement beds in exact stratigraphic position with respect to each other. Upward vertical fracture penetration for fractures exposed in pavements is unconstrained because overlying strata are absent, and cross-sectional exposures of the fractured bed at each 
location were rare. Using cross-cutting and abutting relationships from all pavement locations, we constructed a chronology of fracture set formation. Although most fractures are mineral (mostly calcite) filled, barren and partially filled fractures were also present, most commonly subparallel to filled fractures.

Fractured pavements are best exposed in the middle limb of the fold (9 locations), where beds are nearly horizontal or dip gently, while backlimb locations (4 locations) were not as well exposed due to erosion, colluvium accumulation, and greater vegetative cover. Nearvertical pavement exposures are present at many locations on the steeply dipping forelimb of the anticline, but we were only able to safely access three locations for this study, so we have lower confidence in pavement data from the forelimb relative to other structural positions. Data were also collected from 5 locations to the northeast of the fold, including stations 80 - 84 , near the northern and eastern edges of the map (Fig. 1) and station 50, not shown, located 0.4 km east of station 83 (Fig. 1).

To constrain compositional, textural, and chronologic characteristics of fracture fill, we collected 39 2.5-cm-diameter core samples of fractures (including the host rock) from many pavement localities. We captured high-resolution (600 dpi) optical scans of cross-sections of each core, and performed optical thin-section petrography on these samples.

\subsection{Cross-sectional fracture mapping}

Where the planar middle limb of the fold is well-exposed in cross section (Fig. 2), we gathered data from 9 thin $(<0.5 \mathrm{~m}$ thick), accessible beds. These beds are stratigraphically below those used for pavement mapping (Fig. 2b). We documented fracture orientation, fracture aperture, and fracture position relative to an arbitrary starting point, with scanlines 
centered on each of 9 beds. Because all four fracture sets display strikes that are oblique to the outcrop face (oriented $075^{\circ}$ ), we corrected for geometric sampling bias based on an application of the Terzaghi (1965) method (Fig. 3). All corrected scanline length values $\left(\boldsymbol{L}_{\text {cor. }}\right)$, which are shorter than the uncorrected scanline length $\left(\boldsymbol{L}_{\text {unc. }}\right)$ (Table 1$)$, affect average spacing, fracture intensity, and finite extensional strain (\%e). Here, we calculate fracture intensity values by dividing the number of fractures by scanline length, and calculate finite extensional strain (\%e) by dividing the change in length (based on cumulative aperture of all fractures) by the original, undeformed length and multiplying by $100 \%$.

Fracture aperture was measured using a hand lens and a fracture aperture comparator that permits direct documentation of apertures as small as $0.050 \mathrm{~mm}$, as described by Ortega et al. (2006). We only present data from cement-filled fractures in order to eliminate apertures from barren fractures possibly associated with outcrop weathering and erosion (25 of 470 fractures were eliminated).

We also documented fracture bed boundedness, following a classification similar to Hooker et al. (2013), to describe the relative vertical persistence of fractures (e.g., Gillespie et al., 2001; Strijker et al., 2012). For each fracture, we documented whether the upper tip reached or terminated against the upper bed contact and whether the lower tip reached or terminated against the lower bed contact. If a fracture terminated against the upper and lower contacts of the bed, we considered that fracture perfectly bed-bounded. If a fracture crossed either or both the upper or lower bed contact, we documented where the tip of that fracture terminated in beds or at bed contacts above or below. If a fracture's upper and lower tips terminated at bed contacts but the fracture crosses more than one bed, we termed it bed- 
bounded. Fractures could also display one tip that terminated at a contact and one tip that terminated within a bed (top-bounded or bottom-bounded). Finally, if both the upper and lower tips of a fracture terminated within beds and not at contacts, we considered the fracture unbounded.

We calculate the fracture spacing to layer thickness ratios $\left(S / T_{f}\right)$ of Bai and Pollard (2000a; 2000b) for all sets in each bed. This calculation permits us to consider the possible sequential infilling of fractures within a given layer (Hobbs, 1967; Gross, 1993), with new fractures more likely to form in intact rock than where fractures have already formed. This process, demonstrated experimentally by Wu and Pollard (1995), suggests that fractures within a layer will eventually become so closely spaced that with increasing strain, existing fractures will accommodate additional strain without forming new fractures in the intact rock between them; Bai and Pollard (2000a; 2000b) call this state fracture saturation. Although fracture saturation values vary widely in natural systems (see Table 1 in Bai and Pollard, 2000a), Bai and Pollard (2000b) consider $S / T_{f}$ values above 1.2 to represent fracture spacings below fracture saturation.

Finally, we quantify the regularity of fracture spacing for each bed and for each set, using the coefficient of variation, $C_{v}$, defined as $C_{v}=\sigma / \mu$, where $\sigma$ is the standard deviation of the inter-fracture spacing population and where $\mu$ is the mean of the same population (e.g., Kagan and Jackson, 1991; Gillespie et al., 1999; Supak et al., 2006; Hooker et al., 2013). If fracture spacing is perfectly regular, with identical inter-fracture spacings, the $C_{v}$ value will be zero. As $C_{v}$ increases, the relative clustering increases as well. At a $C_{v}$ value of 1 , a bed displays randomly positioned (but not regularly spaced) fractures (Gillespie et al., 1999). At $C_{v}$ values 
above 1 , clustering is greater than for a randomly distributed fracture population (e.g., Gillespie et al., 1999). We do not calculate $C_{v}$ values for fracture sets with fewer than 5 fractures in a bed (Table 1).

Importantly, we do not address statistical scaling of any measure of our fracture system. Bonnet et al. (2001) suggest a minimum of 200 fractures to accurately define any power-law distribution, and because the number of fractures documented in each limestone bed or from a given fracture set falls below that minimum (Table 1), we cannot confidently quantify a scalable power-law distribution for any fracture characteristic (e.g., aperture, length).

\section{Results and Interpretation}

\subsection{Shear accommodation}

At several outcrops along the steeply ENE-dipping forelimb of the anticline (Figs. 1 and 2), slickenlines on the base and top of beds are oriented perpendicular to the fold axis. When viewed down-dip, these inter-layer slip planes commonly ramp up or down both laterally (parallel to the fold axis) and across beds at low angles (perpendicular to the fold axis). These faults connect with other planes of inter-layer slip and resulting in a fault network with local frontal and lateral ramps but most strain accommodated at bed interfaces (Figs. 4a and 4b).

This is consistent with flexural slip processes that partition strain so that bed contacts accommodate most shear (e.g., Couples et al., 1998). Although the forelimb has accommodated more shear strain than the middle limb of the fold (Surpless et al., 2015), we suggest that even at low strain values, interlayer slip may play a role in the accommodation of extension and/or low-magnitude shear strain. 
We did not observe outcrop-scale contractional deformation in the planar middle limb

or backlimb of the anticline, suggesting that strata in the forelimb hinge (Surpless et al., 2015) and forelimb (this study) accommodated most fold-related strain and, at least locally, the Santa Elena Limestone did not accommodate measureable, layer-parallel shortening prior to fold formation. This contrasts with the findings of Ferrill et al. (2016), who documented lowdisplacement $(0.5 \mathrm{~cm}-9 \mathrm{~cm})$ thrusts in the overlying Boquillas Formation exposed in the nearby Ernst Tinaja (approx. $45 \mathrm{~km}$ south of the Stillwell anticline) that are not associated with fold formation. Because Surpless et al. (2015) documented higher-order folding in the Boquillas Formation (see Fig. 6 in Surpless et al., 2015) in an area where the Santa Elena Limestone displays no similar deformation, we suggest that the thinly bedded, less-competent Boquillas Formation may more readily record early, low-magnitude, layer-parallel shortening. This is also consistent with the idea that the orientation and complexity of fracture systems developed in contractional fold-thrust belts vary spatially, structurally, and stratigraphically across a thrust system (e.g., Evans et al., 2014).

\subsection{Fractured pavements}

Our laboratory analysis of projected fracture data revealed four steeply dipping fracture sets at high angles to pavement surfaces, consistent with field observations where we identified potential fracture sets (e.g., Fig. 4c). At pavement locations, most fractures display horizontal lengths of $\geq 1 \mathrm{~m}$, but data were also gathered from shorter fractures (e.g., set $F_{4}$ fractures in Fig. 4c). We note that a given set's strike value varies slightly by location, similar to the findings of Ladeira (1978; as described in Price and Cosgrove, 1990) and Watkins et al. (2015). Some of the site-to-site variability may also be related to minor lithologic variations, where differences in 
mud content, dolomitization, differences in cementation (Watkins et al., 2015) or variations in local deformational boundary conditions (Olsen et al., 2009) can lead to different fracture patterns even at the same structural position in the anticline. Therefore, we include a fracture in a set if it is within $\pm 15^{\circ}$ of the set's average strike.

Fracture sets include (i) a NW-striking, steeply dipping fracture set subparallel to the NW-trending anticline axis - set $F_{1}, 315^{\circ} \pm 15^{\circ}$; (ii) a steeply dipping, NE-striking fracture set, nearly orthogonal to set $F_{1}$ - set $F_{2}, 045^{\circ} \pm 15^{\circ}$; (iii) a N-striking, steeply dipping fracture set set $F_{3}, 000^{\circ} \pm 15^{\circ}$; and (iv) a W- to WNW striking, steeply dipping fracture set - set $F_{4}, 275^{\circ} \pm$ $15^{\circ}$ (Fig. 5). Based on observations of fracture set abutting and cross-cutting relationships, we suggest a tentative order of formation. Fracture sets $F_{1}$ (axis-parallel) and $F_{2}$ (NE-striking) display mutually cross-cutting and/or abutting relationships and pre-date sets $\mathrm{F}_{3}$ ( $\mathrm{N}$-striking) and $F_{4}$ (W-to-WNW-striking). Where sets $F_{3}$ and $F_{4}$ are present and interact, $F_{3}$ predates set $F_{4}$ (Fig. 4c).

Within the backlimb of the fold, two prominent, steeply dipping fracture sets are observable at multiple locations, including NW-striking set $F_{1}$ (3 locations) and NE-striking set $F_{2}$ (3 locations). Although other fracture sets are present at backlimb locations, no other fracture set is present at more than one location (Fig. 5). In the middle limb of the fold, fracture pavement data reveal all four steeply dipping fracture sets, including axial-parallel set $F_{1}$ (4 locations), NE-striking set $\mathrm{F}_{2}$ (4 locations), $\mathrm{N}$ - striking fracture set $\mathrm{F}_{3}$ (all locations), and WNWstriking fracture set $\mathrm{F}_{4}$ (4 locations). In the middle limb, no location displays all 4 fracture sets

(Fig. 5). In the three forelimb exposures, we observed axial-parallel set $F_{1}$ (2 locations), NEstriking set $F_{2}$ (2 locations), $N$-striking set $F_{3}$ (2 locations), and $W$ - to WNW-striking set $F_{4}$ (2 
locations) (Fig. 4). At the five locations to the northeast of the anticline (Fig. 1), N-striking set $\mathrm{F}_{3}$ is present at all locations, and a set nearly orthogonal to set $F_{3}$, similar in orientation to set $F_{2}$, is present at three locations (Fig. 5).

Although we would expect all pavement localities to display fracture set $F_{3}$, which is present at all locations to the northeast of the fold, and that pavements from the same structural position should display similar fracture patterns, neither assumption holds for our data. Because the degree of weathering varied by location, it is possible that biotic and abiotic weathering processes may have obscured some small-aperture fractures associated with one or more sets. However, our findings are consistent with studies of the Estremoz-Vila Vicoca anticlinorium in Portugal (Ladeira, 1978; as described in Price and Cosgrove, 1990) and the Achnashellach fold and thrust belt, Scotland (Watkins et al., 2015), where not all fold-related fracture sets were present at each locality. More importantly, pavement data at the same structural position within the fold, in close proximity to each other, and at the same approximate stratigraphic level, commonly displayed different fracture sets, similar to the findings of other researchers at other localities (Schecther et al., 1996; Belayneh and Cosgrove, 2004; Laubach et al., 2014). For instance, Belayneh and Cosgrove (2004) demonstrated that a fracture network within a limestone bed can display significantly different patterns and orientations relative to a bed stratigraphically above or below that bed or even laterally, within the same bed. Therefore, we use all pavement localities to characterize fracture patterns across the Stillwell anticline.

The orientations of fracture sets $F_{1}$ and $F_{2}$ are consistent with extension fractures formed during fault-related fold development. As bed flexure occurs both parallel to and 
perpendicular to the fold axis, longitudinal and transverse fracture sets (see $J_{1}$ and $J_{2}$ in Fig. $2 b$ ) form, consistent with the findings of other workers (e.g., Price, 1966; Price and Cosgrove, 1990, and references therein; Wennberg et al., 2007; Ghosh and Mitra, 2009; Watkins et al., 2015; Jamison, 2016). Although these fracture sets occur in the relatively planar limbs of the anticline, where bed curvature is very low, our findings are consistent with those of other researchers who found constant fracture set orientations across bedding with significantly different curvatures (e.g., Hanks et al., 1997; Ghosh and Mitra, 2009; Watkins et al., 2015). The orientation of fracture set $F_{3}$ is consistent with the orientation of regional Miocene and younger Basin and Range extension (e.g., Muehlberger and Dickerson, 1989) and is approximately perpendicular to the modern minimum compressive stress direction for the area (Hiedbach et al., 2016), suggesting initiation and propagation caused by tensional stresses. Where the set is well exposed, most $F_{4}$ fractures terminate against, or abut, $F_{3}$ fractures, suggesting that set $\mathrm{F}_{4}$ fractures behave as cross-fractures (Fig. 4c).

Dyer (1988) concluded that the earlier, systematic fractures (e.g., set $F_{3}$ ) must be open fractures at the time that non-systematic cross-joints (e.g., set $F_{4}$ ) propagate, so that the earlier set provides a free surface, terminating the later set (abutting relationship). In order to both propagate a new opening-mode fracture and keep an existing fracture open, Gross (1993) suggested that only unloading and exhumation near the Earth's surface could promote tensile stresses in directions perpendicular to each mutually perpendicular set. However, field evidence (Fig. 4c) indicates that some set $F_{3}$ fractures were likely filled when $F_{4}$ fractures formed, so did not provide a free surface to terminate propagating $F_{4}$ fractures (note that $F_{4}$ fractures cut across many $F_{3}$ fractures in Fig. $4 c$ before terminating against an $F_{3}$ fracture). This 
difference in the mechanisms of fracture set formation may have resulted in sets that vary in how systematic and, therefore, predictable they are.

\subsection{Pavement fracture fill characterization}

Fractures at pavement locations are mostly calcite-filled, with fill colors ranging from dark reddish-brown to light tan to translucent white, although partially filled or barren fractures are also present on many pavements. Fracture apertures for a given set (e.g., set $F_{1}$ ) vary widely across the fold system, with fractures ranging from approximately $0.5 \mathrm{~mm}$ to $10 \mathrm{~mm}$. Apertures at a given location are typically similar for all sets present. For instance, at location 57 , fracture apertures for all sets range between $5 \mathrm{~mm}$ and $8 \mathrm{~mm}$, whereas at location 61 , fracture apertures range between $0.5 \mathrm{~mm}$ and $1.0 \mathrm{~mm}$ for both exposed sets (Fig. 4c). Optical scans and petrographic thin sections of fractures reveal blocky, euhedral to subhedral calcite fill is most common, and most fill-host rock boundaries are sharp, suggesting little host-rock-fluid interaction. As with field-based observations, fracture fill characteristics at a given location are similar, regardless of set, but differ from other localities. These compositional and textural similarities also allow us to distinguish three or more generations of fracture fill at many localities based on the same observed color changes affecting fills of all fracture sets present.

For example, the cross-section of a core sample from location 57 displays fracture sets with at least 5 generations of calcite fill, with each fill generation displaying a slightly different color and texture (Fig. 6). In this sample, discontinuous porosity is preserved in intersecting, late-stage, light gray fill (' 5 ' in Fig. 6), with orientations parallel to both set $F_{2}$ and set $F_{3}$ fractures. In some samples of large-aperture $(>5 \mathrm{~mm})$ fractures, small $(<0.5 \mathrm{~mm})$ fractures cut 
392

393

large-aperture-fracture fill or the host-rock at angles nearly parallel to the larger, earlier fractures.

These fill features suggest that fractures, once established, accommodated fractureperpendicular extension, with minor changes in calcite composition (based on cement color differences) and texture over time. Field evidence suggests that these fractures, at right angles to each other (Fig. 6), formed at different times, yet they appear to accommodate similar opening-mode strain in the latest stage of fill, with similar variations in fill color and texture. Because similar patterns of fracture opening and fill appear to affect most fractures at a location and post-date the formation of the latest fracture set, we suggest that unloading during exhumation likely increased many fracture apertures, regardless of orientation, across the fold system.

\subsection{Cross-sectional bed package characterization}

\subsubsection{Lithology and bed contacts}

The ENE-trending, $\mathrm{N}$-facing outcrop (Fig. 2) exposes 9 accessible beds ranging in thickness from 6-47 cm (Fig. 7a). In the field, the slightly weathered limestone is a medium gray color, and fractures are usually filled with milky-white to very light-gray calcite. Thinsection petrography reveals a package of beds dominated by homogeneous, sparse biomicrite (matrix-supported lime-mud matrix with microfossils) with only minor moldic porosity in some samples. However, inter-particle porosity may be present at scales below petrographic analysis (e.g., Scholle and Ulmer-Scholle, 2003). Tinker et al. (2013) characterized the competence of these layers using a type-L Schmidt hammer, following the field methods for Schmidt hammer analysis described by Morris et al. (2009) and Ferrill et al. (2011). Their data reveal rebound (R) 
values from 57 to 62 , which correspond to unconfined compressive strengths of approximately $44 \mathrm{MPa}$ to $63 \mathrm{MPa}$ (Aydin and Basu, 2005), a narrow range for in situ measurement of rock competence (e.g., Aydin and Basu, 2005). These data suggest limestone layers with only minor variations in lithology and competence.

Sparsely distributed nodular chert is present along many contacts, but most beds are bound by limestone-on-limestone contacts, with a "stair-step" outcrop style common. This outcrop style might suggest fine, $\mathrm{mm}$-scale shaley laminae or some other inherent weakness at bed contacts, but we observe no such laminae or other change in lithology at bed contacts. Also, in spite of kinematic modeling that suggests minor shear accommodated within the middle limb stratigraphy (Surpless et al., 2015), we found no field evidence for shear strain in the middle limb of the fold (e.g., slickenlines on the base or top of beds or low-displacement thrust faults).

\subsubsection{Fracture set orientations}

Lower-hemisphere projections of fracture data as area-contoured poles to fracture planes (Fig. 7b) reveal that the same 4 fracture sets defined at the fold scale (Fig. 5) are present in all 9 beds in cross-section, but the number of fractures within each set varies within the stratigraphy (Table 1). NW-striking set $F_{1}$ fractures are present in all beds, but only a few $F_{1}$ fractures are present in Bed 1. NE-striking set $F_{2}$ fractures are present in all beds, but not wellrepresented in Beds 5, 8, and 9. $\mathrm{N}$-striking set $\mathrm{F}_{3}$ fractures are present and well-represented in all beds. W- to WNW-striking fracture set $F_{4}$ fractures are present in all beds, but not wellrepresented in Bed 1 (Table 1). Our results show that although all 4 fracture sets are present 
within all beds, we cannot predict the set-specific population distributions for beds above or below based on the fracture population within one bed (Table 1).

\subsubsection{Fracture intensity and bed thickness}

When all fractures are included, without geometric corrections for orientation, fracture intensities (total number of fractures per uncorrected scanline length) for each bed along the outcrop-face-parallel scanline (oriented $075^{\circ}$ ) range from $7.96 \mathrm{~m}^{-1}-10.30 \mathrm{~m}^{-1}$ (Table 1 and Fig. 7b), with the thinnest bed (Bed 2; 6-cm thick) displaying the highest value and the thickest bed (Bed 4; 47-cm thick) displaying the lowest value, consistent with the expected negatively correlated fracture intensity-bed thickness relationship (e.g., Ladeira and Price, 1981; Narr and Suppe, 1991; Bai and Pollard, 2000a; 2000b). However, this relationship is not well-defined in beds $1,3,6$, and 8 (Fig. 7b).

Figure 8 displays graphical representations of the fracture network. Cross-sectional data clearly display the same 4 fracture sets identified in fractured pavements, and laboratory analysis of these data do not identify new fracture sets. All sets display variation in bedspecific, geometrically corrected (Fig. 3) fracture intensities. $F_{1}$ bed values range from a minimum of $0.54 \mathrm{~m}^{-1}$ in Bed 1 to a maximum of $3.41 \mathrm{~m}^{-1}$ in Bed 3, with an average of $1.91 \mathrm{~m}^{-1}$ for all beds (Table 1; Fig. 8b), $F_{2}$ values range from $0.64 \mathrm{~m}^{-1}$ in Bed 5 to $4.68 \mathrm{~m}^{-1}$ in Bed 1, with an average of $2.20 \mathrm{~m}^{-1}$ for all beds (Table 1; Fig. 8c), $F_{3}$ values range from $0.73 \mathrm{~m}^{-1}$ in Bed 1 to $3.98 \mathrm{~m}^{-1}$ in Bed 9 , with an average of $2.70 \mathrm{~m}^{-1}$ for all beds (Table 1; Fig. $8 \mathrm{~d}$ ); and $\mathrm{F}_{4}$ values range from $1.33 \mathrm{~m}^{-1}$ in Bed 3 to $6.85 \mathrm{~m}^{-1}$ in Bed 1, with an average of $4.23 \mathrm{~m}^{-1}$ for all beds (Table 1; Fig. 8e). This variation in set-specific intensities is consistent with fold-scale pavement data and the findings of other researchers, which have shown that a bed may display different fracture 
457

intensities or orientations relative to beds stratigraphically above or below it (e.g., Belayneh and Cosgrove, 2004). Importantly, these relative ranges in bed-specific, corrected fracture intensities for each set are greater than when all fractures for a given bed were considered together along the uncorrected, outcrop-parallel scanline (i.e., total range $7.96 \mathrm{~m}^{-1}-10.30 \mathrm{~m}^{-1}$ ). We also analyzed the relationship between geometrically corrected fracture intensity and bed thickness for the 4 fracture sets (Fig. 8g). Sets $F_{1}$ and $F_{2}$ fracture intensity-bed thickness data display a general decrease in fracture intensity with increase in bed thickness, consistent with fracture theory (e.g., Ladeira and Price, 1981), while fracture sets $F_{3}$ and $F_{4}$ do not. In fact, set $\mathrm{F}_{3}$ displays higher values in beds thicker than $20 \mathrm{~cm}$ relative to thinner beds, and both sets $F_{3}$ and $F_{4}$ display elevated fracture intensity values in thicker beds relative to sets $F_{1}$ and $F_{2}$ (Fig. 8g).

We further evaluate these sets using the $S / T_{f}$ ratio for beds throughout the stratigraphy (Fig. 8h), which reveals that for beds thinner than $20 \mathrm{~cm}$, most fracture sets display wider fracture spacing than the saturation level defined for opening mode fractures ( $>1.2$; Bai and Pollard, 2000b). In contrast, most fracture sets in beds thicker than $20 \mathrm{~cm}$ display $S / T_{f}$ ratios near the spacing saturation level $(0.8-1.2)$. This finding implies that the thicker beds analyzed here would more likely accommodate new extensional strain by expanding existing fracture apertures if placed under tensile stress in any map-view orientation, while new fractures would form and accommodate strain in thinner beds, thus increasing fracture intensity and decreasing the $S / T_{f}$ ratio. Note that applying this ratio here assumes that the extension fracture remains open, so that later extension fractures must form in the intervals between two earlier-formed 
478

fractures due to stress transferred from layers above and below (e.g., Hobbs, 1967; Narr and Suppe, 1991; Rives et al., 1992; Gross, 1993; Bai and Pollard, 2000a; 2000b). However, we also must consider how a filled fracture will impact the accommodation of new strain when considering the implications of how fracture intensity or the $S / T_{f}$ ratio varies with bed thickness, especially in a rock with fractures of multiple orientations. If fractures within a set are cemented soon after forming, the tensile strength of the rock is greater than an open fracture but likely weaker than intact rock. Additionally, the presence of a barren fracture of another set or a fracture filled with weaker cement would also impact whether a new fracture will form in intact rock or whether an existing fracture (or fractures) will accommodate new strain by reactivating filled or barren fractures.

Our results indicate that as a fracture network evolves on the fold or at regional scale, with both filled and barren fracture sets of multiple orientations affecting the rock volume, the theoretical measures used to predict fracture intensities or spacings in well-bedded rocks (e.g., F.I. or $S / T_{f}$ ) become more difficult to apply. In our fracture intensity-bed thickness data (Fig. $8 \mathrm{~g}$ ), fracture sets $F_{1}$ and $F_{2}$ would have initiated and propagated in relatively intact carbonate layers, but sets $\mathrm{F}_{3}$ and $\mathrm{F}_{4}$ would have propagated in fractured rock with an unknown distribution of open, filled, or partially filled fractures, perhaps explaining the enigmatic intensity-thickness relationships displayed by those sets (Fig. 8g). Our data show that as a fracture network with multiple fracture sets develops, total fracture intensity along an arbitrarily oriented scanline (such as an outcrop-parallel scanline) will increase in concert with a decrease in the relative differences between beds.

\subsubsection{Fracture spacing}


variability in fracture intensity across each bed in the stratigraphy (Fig. 8a). The locations of

fracture distributions with higher intensities than the average do not correlate well with the locations of similar distributions in beds above or below. In addition, the width of these zones of higher fracture intensity varies both within beds and from bed to bed. To better document variations in intensity, we use $C_{v}$ values to quantify relative clustering of each of the 4 fracture sets in each bed (Table 1; Figs. $8 b-8 e$ ).

Our analysis reveals that significant clustering $\left(C_{v}>1.000\right)$ is only present in 3 or fewer of the 9 beds for each set (Table 1 and Figs. $8 b-8 e$ ). Three beds display significant $F_{1}$ clustering (beds 3, 6, and 7), two beds display significant $F_{2}$ clustering (beds 2 and 7), two beds display significant $F_{3}$ clustering (beds 5 and 9), and one bed displays significant $F_{4}$ clustering (bed 2) (Table 1 and Fig. 8). Based on these data, we consider our fracture network to be dominated by anticlustering (e.g., Gillespie et al., 1993), with fractures more regularly spaced than in a random distribution. The high-fracture-intensity zones noted in Figure 8a may be due, in part, to the sequential cementing of fractures; cementation eliminates the stress shadow around an open fracture (e.g., Pollard and Segall, 1987), so that new fractures can form in close proximity to existing, filled fractures.

\subsubsection{Fracture aperture}

Average apertures in individual beds for fractures of all orientations ranged from 0.279 $\mathrm{mm}$ (Bed 5) to $0.561 \mathrm{~mm}$ (Bed 4), with variation in standard deviation values from bed to bed (Table 1). Thus, most fractures observed in cross-section display apertures smaller than apertures observed at most pavement locations. The average apertures for the 4 fracture sets 
$522\left(F_{1}-F_{4}\right)$ in the cross section exposure displayed a greater range in values, from a minimum of $0.216 \mathrm{~mm}\left(F_{2}\right.$ fractures in Bed 1) to a maximum of $2.457 \mathrm{~mm}$ ( $F_{2}$ fractures in Bed 4) (Table 1$)$, with a range in standard deviation values (Table 1). These values are affected by three fractures with apertures far above the averages for those beds, including a $10-\mathrm{mm}$ wide $\mathrm{F}_{2}$ fracture in Bed 4 (at scanline position $0.47 \mathrm{~m}$ ), a 2.65- $\mathrm{mm}$ wide $F_{4}$ fracture in Bed 6 (at scanline position $0.80 \mathrm{~m}$ ), and a 3.30- $\mathrm{mm}$ wide $\mathrm{F}_{4}$ fracture in Bed 6 (at scanline position $1.35 \mathrm{~m}$ ). To quantify the strain accommodation both horizontally and vertically, we analyzed cumulative aperture accommodated by each bed for each set as well as documenting cumulative aperture by each fracture set throughout the stratigraphy (Table 1; Fig. 9). In many cases, beds stratigraphically above and below a given bed display very different cumulative aperture profiles. For instance, in the case of the largest fractures (Beds 4 and 6 fractures indicated in Figs. 9b and 9c), the beds above and below those bed-scale fractures do not display similar opening widths for those sets adjacent to those positions. Also, for each set (Figs. 9a $9 d$ ), the bed-specific cumulative apertures (the total opening accommodated across an entire bed) vary widely through the stratigraphy, with maximum values an order of magnitude higher than minimum values in most cases, consistent with the findings of Ortega et al. (2006). the stratigraphy for each set, display profiles with relatively constant slopes across the study outcrop (Fig. 9e). Although the profile for set $F_{2}$ displays a steep slope near $0.50 \mathrm{~m}$, associated with the single large-aperture fracture $(10 \mathrm{~mm})$, and displays a shallower slope from $3.00 \mathrm{~m}$ to the end of the scanline, it, too, reveals relatively constant opening per unit length accommodated throughout the stratigraphy. Similarly, when all fractures are considered for 
each bed (Fig. 9f), nearly all beds appear to have accommodated similar total cumulative opening magnitudes along the scanline. Although the profiles displayed in Figures $9 \mathrm{e}$ and $9 \mathrm{f}$ cannot be used to quantify strain, they do provide information about the qualitative horizontal and vertical distribution of fracture opening.

The relationship between fracture intensity and cumulative aperture is relatively linear, with higher cumulative apertures associated with beds that have higher fracture intensities (Fig. 9g). This relationship holds true for nearly all beds and all fracture sets, suggesting relatively constant fracture apertures for all fracture sets and beds. Thus, strain appears to be evenly distributed through the stratigraphy, regardless of bed thickness. Additionally, percent extension (\%e) values, although low, suggest that the stack of nine beds included in this study do not have a dominant elongation direction associated with one of the four fracture sets. Although fracture set $\mathrm{F}_{4}$ accommodated more extension than any other fracture set for all beds in the stratigraphy (Fig. 9h; Table 1), we think this result may be due to unintended sampling bias (e.g., Bonnet et al., 2001); fracture set $\mathrm{F}_{4}$ is at such a low angle to the outcrop face (Fig. 3) that we may have sampled an unusually high number of $\mathrm{F}_{4}$ fractures relative to the true fracture distribution. Moreover, if set $\mathrm{F}_{4}$ is indeed a non-systematic cross-fracture set (Section 4.2), we might expect greater variability in intensity across the fold system.

\subsubsection{Fracture vertical persistence}

The fracture sets described here exhibit the full range of possible fracture - bed contact interactions described by Hooker et al. (2013), from perfectly bed-bound to unbound fractures (Figs. 8 and 10; Table 2). With the exception of the contact between Beds 5 and 6 , which does not appear to differ from other contacts in the field, the percent of fractures from fracture sets 
that breach each bedding contact is relatively similar, but there is more variation in the percent breached when comparing one contact to another (Fig. 10a). The percent bed-bound fractures is more variable by bed, with the greatest variability between sets displayed in Beds 1, 6, 7, and 9 (Fig. 10b). Most of the remaining beds display less than $50 \%$ bedbound fractures for all sets (Fig. 10b), suggesting that most fractures breach the contact above and/or below. For the four fracture sets, multiple-bed fractures make up between $12.8 \%$ and $19.6 \%$ of each fracture set, with fractures at other orientations displaying multi-bed fractures that make up only $4.7 \%$ of the population (Fig. 10b-10f; Table 2). We suggest that these "not-in-set" fractures are nonsystematic and are likely associated with local perturbations in the stress field within beds and between other fractures, and therefore display less vertical persistence.

\section{Discussion}

\subsection{Relationship of fractures to regional and fold-related stresses}

We attribute the formation of fracture sets $F_{1}$ and $F_{2}$, with orientations similar to theoretical fracture sets $J_{1}$ and $J_{2}$ of Price (1966) (Fig. 3), to stresses related to the formation of the Laramide-age Stillwell anticline. We hypothesize that these longitudinal and transverse fracture sets formed under outer-arc tension as low-magnitude bed flexure occurred both parallel and perpendicular to the fold axis. In the case of fracture set $F_{1}$, bed flexure was perpendicular to the fold axis and is associated with propagation of the underlying fault system, while set $F_{2}$ formed due to bed flexure parallel to the fold axis, caused by variations in fault displacement and resulting fold geometry documented by Surpless et al. (2015). Alternatively, fracture set $F_{2}$, approximately parallel to the regional maximum compressive stress during Laramide time (e.g., Ferrill et al., 2016), may have formed prior to 
fold formation. Shortening-parallel extension fractures are common within and adjacent to contractional fold-thrust belts, forming prior to macroscale folds (e.g., Nickelson and Hough, 1967; Engelder, 1985; Dunne and North, 1990; Evans et al., 2014; Wilkins et al., 2014). In these cases, fractures form in a strike-slip stress regime, with $\sigma_{3}$ in the horizontal plane, perpendicular to the fracture set (e.g., Engelder, 1985). However, abutting relationships from fracture pavement data do not support the formation of NE-striking fracture set $\mathrm{F}_{2}$ prior to $\mathrm{NW}$-striking fracture set $\mathrm{F}_{1}$; pavement data instead support synchronous formation of both fracture sets during local fold formation. In addition, because the strike of extensional fracture set $F_{1}$ is perpendicular to the approximate maximum principal stress $\left(\sigma_{1}\right)$ during Laramide time (e.g., Ferrill et al., 2016), opening could not occur parallel to $\sigma_{1}$, providing additional support for fracture set formation during fold-related bed flexure. This result is consistent with another local study of fracture sets in the Santa Elena Limestone. Smart et al. (2010) documented strain accommodation associated with the Big Brushy Canyon monocline, approximately $10 \mathrm{~km}$ southeast of the Stillwell anticline, and demonstrated that orthogonal, NNW-striking and ENE-striking fracture sets were more closely related to the adjacent, steeply dipping, NNW-striking normal fault than to the regional stress field.

These two extensional, fold-related fracture sets $\left(F_{1}\right.$ and $\left.F_{2}\right)$ appear to be more common in fold limbs than theoretical fracture sets $S_{1}$ and $S_{2}$ (Fig. 3; e.g., Hanks et al., 1997; Ghosh and Mitra, 2009; Watkins et al., 2015). Where fracture sets $S_{1}$ and $S_{2}$ are absent from similar fold systems, low magnitude contractional strain may be taken up by pre-failure mechanisms such as calcite twinning, micro-fracturing, or pressure solution (Hanks et al., 1997; Watkins et al., 
610

2015). The absence of these shear fractures in a contractional fold might also be related to the local stress field. Because fold-related shear fractures sets $S_{1}$ and $S_{2}$ form in a strike-slip stress regime (Section 2.2), if $\sigma_{3}$ is vertical, as we would expect during Laramide compression, theoretical fracture sets $S_{1}$ and $S_{2}$ would not form.

The transition from Laramide-age contraction to Basin and Range extension occurred sometime between $47 \mathrm{Ma}$ (e.g., Miggins, 2009) and 30 Ma (e.g., Price and Henry, 1984), with faulting and basin development in the region well-established by $23 \mathrm{Ma}$ (e.g., Henry et al., 1983; Henry and Price, 1986; Turner et al., 2011). Studies focused on footwalls of Basin and Range normal faults at Big Brushy Canyon (Smart et al., 2010) and Ernst Tinaja (Ferrill et al., 2016; McGinnis et al., 2017) document fracture sets associated with Basin and Range extension. At both localities, researchers show orthogonal extensional fracture sets consistent with the orientations of the fault, with one fracture set subparallel to fault strike and one perpendicular to strike.

Within the Stillwell anticline, we suggest that fracture set $F_{3}$ formed both within the anticline and in flat-lying strata to the northeast as Basin and Range extension affected the region, long after the initiation and propagation of fracture sets $F_{1}$ and $F_{2}$. These fractures likely formed during a prolonged period of uplift and erosion that began during Laramide deformation and continues today, such that rocks exposed in the anticline were likely within 1 $\mathrm{km}$ of the Earth's surface by the time fracture set $F_{3}$ formed. This near-surface environment may have favored the development of fracture set $F_{4}$, which we interpret as a non-systematic cross-fracture set (Fig. 4c) (e.g., Dyer, 1988; Gross, 1993).

5.2. Role of layer-contact properties in fracture network development 
We demonstrated that the same 4 fracture sets defined by pavement data are present in cross-section, and showed that the set-specific fracture populations, intensities, and spatial distributions displayed in one bed commonly differ from beds above and below or from one pavement locality to the next. We suggest that the strength of coupling between beds in the stratigraphy of planar fold limbs influences fracture network development as much as structural position, helping to explain the differences between fracture sets present at pavement localities and in cross-sectional fracture data. Our results are consistent with other investigations of the intensity and vertical extent of opening - mode fractures in well-stratified sedimentary rocks, with interlayer contacts playing a major role in network development (e.g., Becker and Gross, 1996; Schether et al., 1996; Hanks et al., 1997; Underwood et al., 2003; Belayneh and Cosgrove, 2004; Laubach et al., 2014).

Smart et al. (2009) used finite element modeling to test the effects of changing the strength of coupling between beds within a fault-propagation fold to determine the impact of interlayer slip upon strain magnitude and distribution. When Smart et al. (2009) permitted inter-layer slip in the model, results revealed a strikingly heterogeneous distribution of strain, with bed contacts commonly acting as barriers to the propagation of strain. For instance, where strain was high in one bed, the bed above or below it commonly displayed very different distributions and/or magnitudes of strain (see Fig. 6 in Smart et al., 2009). In contrast, when Smart et al. (2009) prevented inter-layer slip between beds, the spatial strain distribution was predictable and controlled primarily by structural position within the fold (Smart et al., 2009). Thus, when a fold forms in well-stratified sedimentary rocks with weak coupling between 
653

layers, the distribution of strain will be more complex than in a fold that deforms either massive beds or a stratigraphy with strongly coupled beds.

We rely on Smart et al. (2009) and previous studies (e.g., Martel et al., 1988; Cruikshank, 1991; Cruikshank and Aydin, 1994; Cooke, 1997; Cooke et al., 2000; Underwood et al., 2003;

Laubach et al., 2009) to suggest a physical mechanism the explains why we observe differences in the accommodation of strain from layer to layer and yet document a relatively constant and evenly distributed total strain associated with each layer and fracture set. When an openingmode fracture forms in one layer and propagates through the entire layer thickness, the body of rock on each side of the fracture is displaced in a direction perpendicular to the fracture plane. If the layer above is strongly coupled with the fractured bed, then fracture propagation may continue past that contact into the upper bed, perhaps terminating within that bed, similar to what we observe in many fractures in cross-section (Figs. 8 and 10). However, if a fracture terminates at a bed contact, we can assume that some combination of interface slip and debonding between layers has taken place, reducing the local shear stress and likelihood of continued vertical propagation (e.g., Cooke et al., 2000; Cooke and Underwood, 2001; Underwood et al., 2003). Importantly, any flexural slip during fold formation, expected with fold-related sets $F_{1}$ and $F_{2}$, will likely result in partitioning between transverse longitudinal strain within the beds and shear strain focused along bedding interfaces (e.g., Ramsay, 1967; Bayly, 1992; Couples et al., 1998).

Although we find no evidence for shear strain within the middle limb of the anticline, the inter-layer slip documented in the forelimb of the Stillwell anticline (Fig. 4) supports the idea that bed contacts are planes of weakness along which low-magnitude, layer-parallel strain 
675

might decouple one bed from the next. If the strength of coupling remained constant along a given contact, it would be easier, mechanically, to localize shear along that contact. However, the frequent lateral and frontal ramps documented along the forelimb suggests lateral variability in the strength of coupling between beds.

$$
\text { Variation in cohesion between beds (Fig. 10), combined with the low total strain }
$$
accommodated in the planar middle limb of the anticline (Table 1), helps explain the lack of vertical persistence for most fractures (Fig. 8). Previous workers have shown that vertically persistent, through-going joints develop subsequent to bed-bound joints, with vertically persistent joints developing only after a critical level of strain is achieved across all layers in the stratigraphy (e.g., Becker and Gross, 1996; Shackleton et al., 2005; Gross and Eyal, 2007).

\subsection{Implications for fracture network development in planar fold limbs}

Our findings should aid in predicting features of a fracture network in the stratigraphy of a planar fold limb. The cumulative aperture profiles, when all fractures are included, are remarkably similar for all beds in the stratigraphy (Fig. 9f), with total opening widths of approximately $2-3 \mathrm{~mm} / \mathrm{m}$. Although fracture intensity varies significantly, the cumulative aperture for a given bed is predictable, with a nearly linear relationship between fracture intensity and cumulative aperture (Fig. 9g). In both cases, this predictability is controlled by the relatively similar apertures and distributions (as measured by $C_{v}$ ) of fractures, regardless of set (Table 1). In addition, the orientation of fracture sets documented in pavements, which expose larger-aperture fractures, remains constant in fractures exposed in cross-section, suggesting fracture set orientations remain relatively constant across spatial scales. 
In a similar fold-related fracture study, Jamison (2016) used four well-exposed fold exposures with a range of geometries to represent stages of anticline development. In his model, as the fold tightened, fracture intensities in the planar limbs increased and variability of orientations for each fracture set increased in concert (Jamison, 2016). This is consistent with the local perturbation of fold-related stresses expected within layers as fractures form and propagate, with each new fracture affecting the stress field around it (e.g., Bai and Pollard, 2000a; 2000b). As the intensity of fractures of all orientations increase both during and after fold formation, we would predict an increase in fracture orientation variability associated with the increasing number of discontinuities (fractures) within each layer, consistent with the findings of Jamison (2016).

The fracture lengths ( $\geq 1 \mathrm{~m}$ ) common in pavements (e.g., Fig. $4 \mathrm{c}$ ), the variability of orientations within each fracture set, and the high-angle relationships between the 4 fracture sets support the potential for high connectivity (e.g., Odling, 1992; Odling et al., 1999; Gudmundsson, 2011) in spite of the relatively low documented strains accommodated by fractures. Although we cannot establish the absolute timing of fracture formation relative to kinematic opening, many fractures from all fracture sets documented in pavements experienced multiple generations of opening and cementation. Some portion of the kinematic opening of these fractures took place during a protracted unloading process as these rocks rose from maximum burial depth to the surface. It is also likely that additional propagation and kinematic opening of existing fractures took place as these rocks approached the surface, at depths less than 500 m (e.g., Engelder, 1985). 
Although new joints related to the unloading process may form and propagate as rocks approach the surface during exhumation, Engelder (1985) showed that unloading joints form prior to exposure and are related to residual tectonic stress, existing structures, or the contemporary tectonic stress field (in our case, that of the modern Basin and Range Province).

Thus, we suggest that the systematic nature of our fracture network, the clear relationship between each fracture set orientation and a tectonic or fold-related stress, and the lack of evidence for fracture formation by surface processes permit future researchers to apply our results to fracture networks in layered stratigraphy across a range of settings.

\section{Conclusions}

The well-exposed Stillwell anticline presents an excellent opportunity to constrain development of a finite fracture network using field-based documentation of outcrop-scale fracturing. Our investigation provides new data that other researchers can apply to similar contractional dip-domain folds in layered carbonate rocks. These results have implications for evaluating fracture-related fluid flow in the low-strain, planar limbs of contractional fault propagation folds and in studies where multiple episodes of deformation have impacted a rock volume with a well-defined stratigraphy. Our results yield the following conclusions.

1) Fracture set orientations exposed in pavements and in cross section are related to bed flexure (sets $F_{1}$ and $F_{2}$ ), regional tectonic (set $F_{3}$ ), and unloading/exhumation (set $F_{4}$ ) processes. All fractures formed under tension, with no evidence for shear or mixed-mode behavior.

2) Spatial variability of fracture patterns in pavements is likely related to some combination of lithologic variation, local perturbations in deformational boundary conditions, and bed-to- 
bed variations accommodated by differences in the strength of coupling between beds. No single pavement locality characterizes the fracture network within a fold limb.

3) Many large-aperture fractures accommodated multiple generations of opening and fill; many of these events, and the formation of some new fractures observed in thin section, are likely related to unloading and exhumation, suggesting that outcrop-based data are more complex than those in the subsurface.

4) In a fold limb with thinly bedded stratigraphy and low total strains, we would predict formation of the same fracture sets present on the fold scale, but each layer would likely exhibit significant variation in the percentages of each set present and the set-specific (Bai and Pollard, 2000a; 2000b) difficult to apply.

5) In the same stratigraphy, the cumulative strains accommodated by each bed for each fracture set should be similar, with relatively regularly spaced (based on $C_{v}$ value) fractures for most sets. If these sets are at high angles to each other, fracture connectivity in each

6) The low total strains and variability in bed-contact properties result in few fractures with significant vertical persistence, suggesting low vertical connectivity.

These outcrop-based results provide information to assess similar subsurface structures, gas reservoirs. 
761

\section{References}

Abritton, D., Jr., Smith, J., Jr., 1957. The Texas lineament. Proceedings, Twentieth International Geological Congress, Mexico City, sec. 5, $501-518$.

Aydin, A., A. Basu, 2005. The Schmidt hammer in rock material characterization. Engineering Geology 81, 1-14, doi:10.1016/j.enggeo.2005.06.006.

Bai, T., Pollard, D., 2000a. Fracture spacing in layered rocks: a new explanation based on the stress transition. Journal of Structural Geology 22, 43-57.

Bai, T., Pollard, D., 2000b. Closely spaced fractures in layered rocks: initiation mechanism and propagation kinematics. Journal of Structural Geology 22, 1409-1425.

Bayly, B., 1992. Mechanics in Structural Geology. Springer-Verlag, New York, 253 p.

Becker, A., Gross, M., 1996. Mechanisms for joint saturation in mechanically layered rocks: an example from southern Israel. Tectonophysics 257, $223-237$.

Belayneh, M., Cosgrove, J., 2004. Fracture pattern variations around a major fold and their implications regarding fracture prediction using limited data: an example from the Bristol Channel Basin. In: Cosgrove, J., Engelder, T. (Eds.), The Initiation and Propagation, and Arrest of Joints and Other Fractures: Geological Society of London, Special Publications 231, $89-102$.

Bergbauer, S., Pollard, D., 2004. A new conceptual fold-fracture model including prefolding joints, based on field data from the Emigrant Gap anticline, Wyoming. Geological Society of America Bulletin 116, $294-307$.

Bonnet, E., Bour, O., Odling, N., Davy, P., Main, I., Cowie, P., Berkowitz, B., 2001. Scaling of fracture systems in geological media. Reviews of Geophysics 29, $347-383$. 
Cooke, 1997. Fracture localization along faults with spatially varying friction. Journal of Geophysical Research 102, 22,425 - 22,434.

Cooke, M., Mollema, P., Pollard, D., Aydin, A., 2000. Interlayer slip and joint localization in the East Kaibab Monocline, Utah: field evidence and results from numerical modelling. In: Cosgrove, J., Ameen, M. (Eds.), Forced Folds and Fractures, Geological Society of London $169,23-49$.

Cooke, M., Underwood, C., 2001. Fracture termination and step-over at bedding interfaces due to frictional slip and interface opening. Journal of Structural Geology 23, $223-238$.

Cooper, M., 1992. The analysis of fracture systems in subsurface thrust structures from the Foothills of the Canadian Rockies. In: McClay, K.R. (Ed.), Thrust Tectonics. Chapman and Hall, London, 391-405.

Couples, G., Lewis, H., 1998. Lateral variations in strain in experimental forced folds: Tectonophysics 295, $79-91$.

Couples, G., Lewis, H., Tanner, G., 1998. Strain partitioning during flexural slip folding. In: Coward, M., Daltaban, T, Johnson, H. (Eds.), Structural Geology in Reservoir Characterization. Geological Society, London, Special Publications 127, 149-165.

Cruikshank, K., 1991. Analysis of minor fractures associated with joints and faulted joints. Journal of Structural Geology 13, $865-886$.

Cruikshank, K., Aydin, A., 1994. Role of fracture localization in arch formation, Arches National Park, Utah. Geological Society of America Bulletin 106, 879 - 891.

Dunne, W. M., and C. P. North, 1990. Orthogonal fracture systems at the limits of thrusting: an example from southwestern Wales. Journal of Structural Geology 12, 207-215. 
805

806

Dyer, R., 1988. Using joint interactions to estimate paleostress ratios. Journal of Structural Geology 10, $685-699$.

Engelder, T., 1985. Loading paths to joint propagation during a tectonic cycle: an example from the Appalachian Plateau, U.S.A. Journal of Structural Geology 7, 459-476.

Evans, M. A., A. DeLisle, J. Leo, C. J. Lafonte, 2014. Deformation conditions for fracturing in the Middle Devonian sequence of the central Appalachians during the Late Paleozoic Alleghenian orogeny. AAPG Bulletin 98, 2263-2299.

Ferrill, D. A., A. P. Morris, K. J. Smart, 2007. Stratigraphic control on extensional fault propagation folding: Big Brushy Canyon monocline, Sierra Del Carmen, Texas. In: Jolley, S.J., Barr, D., Walsh, J.J., Knipe, R.J. (Eds.), Structurally complex reservoirs. Geological Society of London Special Publication 292, 203-217.

Ferrill, D.A., Morris, A.P., McGinnis, R.N., Smart, K., Ward, W., 2011. Fault zone deformation and displacement partitioning in mechanically layered carbonates: The Hidden Valley fault, central Texas. American Association of Petroleum Geologists 95, 1383-1397.

Ferrill, D.A., Morris, A.P., Wigginton, S.S., Smart, K.J., McGinnis, R.N., Lehrmann, D., 2016. Deciphering thrust fault nucleation and propagation and the importance of footwall synclines. Journal of Structural Geology 85, 1-11.

Fischer, M., Wilkerson, M., 2000. Predicting the orientation of joints from fold shape: results of pseudo-three-dimensional modeling and curvature analysis. Geology 28, $15-18$.

Friedman, M., 1969. Structural analysis of fractures in cores from the Saticoy Field, Ventura Co., California. American Association of Petroleum Geologists Bulletin 53, 367 - 389. 
Ghosh, K., Mitra, S., 2009. Structural controls of fracture orientations, intensity, and connectivity, Teton anticline, Sawtooth Range, Montana. American Association of Petroleum Geologists Bulletin 93, 995-1014.

Gillespie, P.A., Howard, C.B., Walsh, J.J., Watterson, 1993. Measurement and characterization of spatial distributions of fractures. Tectonophysics $226,113-141$.

Gillespie, P.A., Johnston, J.D., Loriga, M.A., McCaffrey, K.J.W., Walsh, J.J., Watterson, J., 1999. Influence of layering on vein systematics in line samples. In: McCaffrey, K.J.W., Lonergan, L., Wilkinson, J.J. (Eds.), Fractures, Fluid Flow and Mineralization. Geological Society, London, Special Publications 155, 35-56.

Gillespie, P.A., Walsh, J.J., Watterson, J., Bonson, C.G., Manzocchi, T., 2001. Scaling relationships of joint and vein arrays from The Burren, Co. Clare, Ireland. Journal of Structural Geology 23, 183-201.

Gross, M., 1993. The origin and spacing of cross joints: examples from the Monterey Formation, Santa Barbara Coastline, California. Journal of Structural Geology 15, 737751.

Gross, M., Eyal, Y., 2007. Throughgoing fractures in layered carbonate rocks. Geological Society of America Bulletin 119, $1387-1404$.

Gudmundsson, A., 2011. Rock Fractures in Geological Processes. 1st ed. Cambridge, UK, Cambridge University Press, 578 p.

Hancock, P. L., 1985. Brittle microtectonics: principles and practice. Journal of Structural Geology 7, 437-457. 
Hanks, C., Lorenz, J., Lawrence, T., Krumhardt, 1997. Lithologic and structural controls on natural fracture distribution and behavior within the Lisburne Group, northeastern Brooks Rand and North Slope subsurface, Alaska. American Association of Petroleum Geologists Bulletin 81, $1700-1720$.

Heidbach, O., Rajabi, M., Reiter, K., Ziegler, M., 2016. World Stress Map 2016. GFZ Data Service, https://doi.org/10.5880/WSM.2016.002.

Henry, C.D., Price, J.G., McDowell, R., 1983. Presence of the Rio Grande rift in West Texas and Chihuahua. El Paso Geological Society Guidebook, no. 15, 108-118.

Henry, C.D., Price, J.G., 1986. Early Basin and Range development in Trans-Pecos Texas and adjacent Chihuahua - Magmatism and orientation, timing, and style of extension. Journal of Geophysical Research 91, 6213-6224.

Hobbs, D., 1967. The formation of tension joints in sedimentary rocks - an explanation. Geological Magazine 104, 550-556.

Hooker, J., Laubach, S., Marrett, R., 2013. Fracture-aperture size-frequency, spatial distribution, and growth processes in strata-bounded and non-strata-bounded fractures, Cambrian Mesón Group, NW Argentina. Journal of Structural Geology 54, 45 - 71.

Jamison, W.R., 2016. Fracture system evolution within the Cardium sandstone, central Alberta Foothills folds. American Association of Petroleum Geologists Bulletin 100, 1099-1134.

Kagan, Y., Jackson, D., 1991. Long-term earthquake clustering. Geophysics Journal International $104,117-133$.

Ladeira, F., 1978. Relationship of fractures to other geological structures in various crustal environments. Ph.D. Thesis, University of London. 
Ladeira, F., Price, N., 1981. Relationship between fracture spacing and bed thickness. Journal of Structural Geology 3, 179-183.

Laubach, S. E., Olson, J. E, Gross, M. R., 2009. Mechanical and fracture stratigraphy. American Association of Petroleum Geologists Bulletin 93, 1413-1426.

Laubach, S.E., Eichhubl, P., Hargrove, P., Ellis, M.A., Hooker, J.N., 2014. Fault core and damage zone fracture attributes vary along strike owing to interaction of fracture growth, quartz accumulation, and differing sandstone composition. Journal of Structural Geology 68, $207-226$.

Lehman, T. L., 1991. Sedimentation and tectonism in the Laramide Tornillo Basin of West Texas: Sedimentary Geology 75, 9-28.

Marrett, R., 1996. Aggregate properties of fracture populations. Journal of Structural Geology 18, 169-178.

Martel, S., Pollard, D., Segall, P., 1988. Development of simple strike-slip fault zones, Mount Abbot quadrangle, Sierra Nevada, California. Geological Society of America Bulletin 100, $1451-1465$.

Maxwell, R., Lonsdale, J., Hazzard, R., Wilson, J., 1967. Geology of Big Bend National Park, Brewster County, Texas. Texas Bureau of Economic Geology Pub. 6711, 320 p., geologic map scale 1:62,500.

McGinnis, R.N., Ferrill, D.A., Smart, K.J., Morris, A.P., Higuera-Diaz, C., Prawica, D., 2015. Pitfalls of using entrenched fracture relationships: Fractures in bedded carbonates of the Hidden Valley fault zone, Canyon Lake Gorge, Comal County, Texas. American Association of Petroleum Geologists Bulletin 99, 2221-2245. 
891

892

893

894

895

896

897

898

899

900

901

902

903

904

905

906

907

908

909

910

McGinnis, R.N., Ferrill, D.A., Morris, A.P., Smart, K.J., Lehrmann, D., 2017. Mechanical stratigraphic controls on natural fracture spacing and penetration. Journal of Structural Geology 95, 160-170.

Miggins, D., 2009. Temporal and Geochemical Insights Related to Volcanic and Plutonic Activity within Big Bend National Park, Texas. Ph.D. Thesis, University of Texas at El Paso, 309p.

Miller, D., Nilsen, T., Bilodeau, W., 1992. Late Cretaceous to early Eocene geologic evolution of the U.S. Cordillera. In: Burchfiel, B., Lipman, P., Zoback, M. (Eds.), The Cordilleran Orogen: conterminous U.S. Geological Society of America G-3, 205 - 260.

Morris, A.P., Ferrill, D.A., McGinnis, R., 2009. Mechanical stratigraphy and faulting in Cretaceous carbonates. American Association of Petroleum Geologists Bulletin 93, 1459-1470.

Moustafa, A.R., 1988. Structural geology of the Sierra del Carmen, Trans-Pecos, Texas. Geological Quadrangle Map GQ-0054, University of Texas at Austin, Bureau of Economic Geology, 28 p.

Muecke, G.K., Charlesworth, H.A.K., 1966. Jointing in folded Cardium Sandstone along the Bow River, Alberta. Canadian Journal of Earth Sciences 3, 579-596.

Muehlberger, W.R., 1980. Texas Lineament Revisited. New Mexico Geological Society Guidebook, $31^{\text {st }}$ Field Conference, Trans-Pecos Region, $113-121$.

Muehlberger, W.R., Dickerson, P.W., 1989. A tectonic history of Trans-Pecos, Texas. In: Muehlberger, W.R., Dickerson, P.W. (Eds.), Structure and stratigraphy of Trans-Pecos Texas: American Geophysical Union Field Trip Guidebook T315, 35 - 54.

Narr, W., Suppe, J., 1991. Joint spacing in sedimentary rocks. Journal of Structural Geology 13, $1037-1048$. 
913

914

Nelson, R., 2001. Geologic analysis of naturally fractured reservoirs, $2^{\text {nd }}$ Ed. Gulf Professional Publishing, Boston, Massachusetts, $332 \mathrm{p}$.

Nickelsen, R.P., Hough, V.D., 1967. Jointing in the Appalachian Plateau of Pennsylvania: Bulletin of the Geological Society of America 78, 609-630.

Odling, N., 1992. Network properties of a two-dimensional natural fracture pattern. Pure and Applied Geophysics 138, $97-114$.

Odling, N., Gillespie, P., Bourgine, B., Castaing, C., Chiles, J-P., Christensen, N., Fillion, E., Genter, A., Olson, C., Thrane, L., Trice, R., Aarseth, E., Walsh, J., Watterson, J., 1999. Variations in fracture system geometry and their implications for fluid flow in fractured hydrocarbon reservoirs. Petroleum Geoscience 5, 373-384.

Olson, J., Laubach, S., Lander, R., 2009. Natural fracture characterization in tight gas sandstones: integrating mechanics and diagenesis. American Association of Petroleum Geologists 93, 1535-1549.

Ortega, O., Marrett, R., Laubach, S., 2006. A scale-independent approach to fracture intensity and average spacing measurement. American Association of Petroleum Geologists Bulletin 90, $193-208$.

Page, W., Turner, K., Bohannon, R., 2008. Geological, Geochemical, and Geophysical Studies by the U.S. Geological Survey in Big Bend National Park, Texas. In: Gray, J., and Page, W. (Eds.), U.S. Geological Survey Circular 1327, 93 p.

Pollard, D., Segall, P., 1987. Theoretical displacements and stresses near fractures in rock: with applications to faults, joints, veins, dikes, and solution surfaces. In: Atkinson, B. (Ed.), Fracture Mechanics of Rock. Academic Press, London, 277 - 350. 
Price, N., 1959. Mechanics of jointing in rocks. Geological Magazine 96, $149-167$.

Price, N., 1966. Fault and Joint Development in Brittle and Semi-brittle Rock. Pergamon Press, Oxford, UK, $176 \mathrm{p}$.

Price, N., Cosgrove, J., 1990. Analysis of Geological Structures. Cambridge Press, Cambridge, UK, $502 \mathrm{p}$.

Price, J.G., Henry, C.D., 1984. Stress orientations during Oligocene volcanism in Trans-Pecos Texas: timing the transition from Laramide compression of Basin and Range tension. Geology 12, 238- 241.

Ramsay, J., 1967. Folding and fracturing of rocks. McGraw - Hill, New York, 560 p.

Rives, T., Razack, M., Petit, J.P., Rawnsley, K.D., 1992. Joint spacing: analogue and numerical simulations. Journal of Structural Geology 14, $925-937$.

St. John, B.E., 1965. Structural geology of Black Gap area, Brewster County, Texas. Ph.D. Thesis, University of Texas at Austin, $200 \mathrm{p}$.

St. John, B.E. 1966. Geology of Black Gap area, Brewster County, Texas. Geological Quadrangle Map GQ-0030, University of Texas at Austin, Bureau of Economic Geology, 18 p.

Schechter, D., McDonald, P., Sheffield, T., 1996. Reservoir characterization and $\mathrm{CO}_{2}$ pilot design in the naturally fractured Spraberry Trend area. Proceedings of the Permian Basin Oil and gas Recovery Conference, Midland, Texas. Society of Petroleum Engineers, 819 - 833.

Scholle, P., Ulmer-Scholle, D., 2003. A color guide to the petrography of carbonate rocks: Grains, Textures, Porosity, and Diagenesis. American Association of Petroleum Geologists Memoir 77, 474 p. 
Shackleton, J.R., Cooke, M.L., Sussman, A.J., 2005. Evidence for temporally changing mechanical stratigraphy and effects on joint-network architecture. Geology 33, 101-104, https://doi.org/10.1130/G20930.1.

Smart, K., Ferrill, D., Morris, A., 2009. Impact of interlayer slip on fracture prediction from geomechanical models of fault-related folds. American Association of Petroleum Geologists Bulletin 93, $1447-1458$.

Smart, K.J., Ferrill, D.A., Morris, A.P., Bichon, B.J, Riha, D.S., and Huyse, L., 2010. Geomechanical modeling of an extensional fault-propagation fold: Big Brushy Canyon monocline, Sierra Del Carmen, Texas. American Association of Petroleum Geologists Bulletin 94, 221-240.

Stearns, D. W., 1968. Certain aspects of fracture in naturally deformed rocks. In: Riecker, R. E. (Ed.), NSF advanced science seminar in rock mechanics. Bedford, Massachusetts, Air Force Cambridge Research Laboratories Special Report, 97-118.

Stearns, D., Friedman, M., 1972. Reservoirs in fractured rocks. American Association of Petroleum Geologists Memoir 16, $82-100$.

Strijker, G., Bertotti, G., Luthi, S.M., 2012. Multi-scale fracture network analysis from an outcrop analogue: a case study from the Cambro-Ordovician clastic succession in Petra, Jordan. Marine and Petroleum Geology 38, 104-116.

Supak, S., Bohnenstiehl, D., Buck, W., 2006. Flexing is not stretching: an analogue study of flexure-induced fault populations. Earth and Planetary Science Letters 246, 125 - 137.

Surpless, B., Hill, N., Beasley, C., 2015. The unusual 3D interplay of basement fault reactivation and fault-propagation-fold development: a case study of the Laramide-age Stillwell anticline, west Texas (USA). Journal of Structural Geology 79, 42 - 56. 
978

Terzaghi R., 1965. Sources of error in joint surveys. Geotechnique 15, 287-304.

Tinker, N., Keesling, G., Mercado, L., Surpless, B., DeZoeten, E., 2013. Topographic profile, mechanical stratigraphy, and interlayer slip - exploring coupled fold-fracture evolution in the Stillwell anticline, west Texas. Geological Society of America Abstracts with Programs 45, No. 3, 77.

Turner, K. J., et al., 2011, Geologic map of Big Bend National Park, Texas: U. S. Geological Survey Scientific Investigations Map 3142, scale 1:75,000, pamphlet, 84 p.

Underwood, C.A., Cooke, M.L., Simon, J.A., Muldoon, M.A., 2003. Stratigraphic controls on vertical fracture patterns in Silurian dolomite, northeastern Wisconsin. American Association of Petroleum Geologists Bulletin 87, 121-142.

Watkins, H., Butler, R., Bond, C., Healy, D., 2015. Influence of structural position on fracture networks in the Torridon Group, Achnashellach fold and thrust belt, NW Scotland. Journal of Structural Geology 74, 64-80.

Wennberg, O.P., Azizzadeh, M., Aqrawi, M.M., Blanc, E., Brockbank, P., Lyslo, K.B., Pickard, N., Salem, L.D., Svånå, T., 2007. The Khaviz Anticline: an outcrop analogue to giant fractured Asmari Formation reservoirs in SW Iran. In: Lonergan, L., Jolly, R.J.H., Rawnsley, K., Sanderson, D.J. (Eds.), Fractured Reservoirs. Geological Society of London Special Publications 270, 23-42.

Wilkins, S. J., V. Mount, K. Mahon, A. Perry, and J. Koenig, 2014. Characterization and development of subsurface fractures observed in the Marcellus Formation, Appalachian Plateau, north-central Pennsylvania. AAPG Bulletin, 98, 2301-2345. 
$999 \mathrm{Wu}$, H., Pollard, D., 1995. An experimental study of the relationship between joint spacing and layer thickness. Journal of Structural Geology 17, 887-905.

Zahm, C. Hennings, P., 2009. Complex fracture development related to stratigraphic architecture: Challenges for structural deformation prediction, Tensleep Sandstone at the Alcova anticline, Wyoming. American Association of Petroleum Geologists Bulletin 93, $1427-1446$. 


\section{FIGURE CAPTIONS:}

Figure 1. A. Shaded relief map with Laramide-age structural data from the Stillwell anticline (SA) region. Structural data include Laramide-age faults and folds, with inset (lower right) showing distribution of deformation associated with the Laramide orogeny. Abbreviations: Sierra del Carmen mountains $=$ SDC, Santiago mountains $=$ SM, and Big Bend National Park $=$ BBNP. The rectangle on thrust faults $/$ monoclines indicates the upthrown side of the fault/monocline system. Distribution of Laramide-age faults and folds modified from Muehlberger and Dickerson (1989) and Page et al. (2008). Inset map modified from Miller et al. (1992). Figure modified from Surpless et al. (2015). B. Geologic map of the Stillwell anticline study area with fracture system observation locations. The Sue Peaks Formation underlies the Santa Elena Limestone but is not exposed in the map area. The location of the cross-sectional exposure displayed in Figure 2 is indicated. Coordinates shown are from UTM Zone 13R. Modified from Surpless et al. (2015).

Figure 2. North-facing, cross-sectional exposure of Stillwell anticline, west Texas, USA. A. Weathering and erosion have cut through the NE-vergent contractional faultpropagation fold, exposing an excellent cross-sectional view of the middle and upper Santa Elena Limestone stratigraphy. The location displayed in Figure 7 is boxed. Due to variations in distances from photographer, scale for the image is approximate, and bed orientations on image should not be considered true dips. Modified from Surpless et al. (2015). B. Schematic overview of anticline field investigation. We focus our study on pavements from three planar limbs of the fold as well as on cross-sectional exposure of 
a package of limestone beds in the middle limb of the anticline (boxed). We include fracture orientations, all normal to bedding planes, expected to form during thrustrelated anticline formation $\left(\mathrm{J}_{1}, \mathrm{~J}_{2}, \mathrm{~S}_{1}\right.$, and $\mathrm{S}_{2}$; orientations modified from Price, 1966).

Figure 3. Plan-view 2D scanline length corrections. Because no fracture set is perpendicular to the outcrop-face-parallel scanline, we correct each fracture set's scanline length $\left(\boldsymbol{L}_{\text {cor. }}\right)$ to reflect its orientation relative to the orientation of the outcrop face-parallel scanline length ( $\left.\boldsymbol{L}_{\text {unc. }}\right)$, using principles established by Terzaghi (1965). These corrections affect fracture position, spacing, and intensity values.

Figure 4. A. Overview of faulted beds in NE-dipping forelimb outcrop, with stained, steeply dipping interlayer slip planes exposed with slickenlines perpendicular to the anticline fold axis. Black box indicates area shown in Figure 4B. Person for scale. B. Close-up view of several contractional faults(dashed white lines), which commonly follow bed contacts but ramp up- or down-section to link with interlayer slip planes. Some exposed interlayer (bed-parallel) faults (exposed at the base of individual beds) are emphasized with shading. Scale shown is approximate due to differences in distance between the outcrop and the photographer. C. Oblique photo of pavement exposure at location 61 (Fig. 1), where fracture sets $F_{3}$ and $F_{4}$ interact on the upper surface of a limestone bed. Note that set $F_{4}$ fractures terminate against $F_{3}$ fractures, suggesting set $F_{4}$ post-dates set $F_{3}$. Scale shown is approximate due to differences in distance between the outcrop and the photographer.

Figure 5. Northern segment fracture data from the Stillwell anticline study area. Fracture data are displayed by structural position and by data collected from locations to the 
northeast of the anticline. The numbers displayed on stereonets correspond to locations shown on Figure 1. The 4 fracture sets described in the text are shown for reference (sets $\left.F_{1}-F_{4}\right)$. All fractures projected on equal-area lower-hemisphere stereonets. Light gray shaded region indicates approximate orientation of anticline fold axis. In cases where pavements were not horizontal, we rotated fracture data to horizontal using 3D rotations about the strike of dipping beds.

Figure 6. High-resolution optical scan of 2.5-cm-diameter core cross-section from location 57, where fractures from sets $F_{2}$ and $F_{3}$ interact. Up is north. A. Unmarked view of core cross-section, displaying fracture fill and host rock. B. Interpreted view of core crosssection, displaying multiple generations of fracture fill (a minimum of 5 fill events), with differing textures and colors. Discontinuous open space is present in what we interpret to be the last generation of fracture fill, colored milky-white to gray.

Figure 7. Cross-sectional fracture data. A. Field photo of study outcrop, highlighting position, thicknesses, and scanline lengths of 9 beds used for fracture study. The exposed outcrop face trends $074^{\circ}$. Dashed lines indicate bottom and top of stratigraphic section documented in this study. Location of outcrop is indicated on Figure 2A. Scale is approximate because of variations in distance from the photographer. B. Lowerhemisphere stereographic projection of fracture data from 9 beds. Equal-area, lowerhemisphere stereonets display bed-scale fractures plotted as planes, and fractures from all beds are plotted as poles to planes and contoured using a $1 \%$ inverse area squared method with a contour interval of two sigma. On the "All Beds" stereonet projection, the four fracture sets identified earlier are plotted as planes and labeled. We display 
1071

1072

1073

1074

1075

1076

1077

1078

1079

1080

1081

1082

1083

1084

the bed-thickness - fracture intensity relationship for the 9 beds in the graph at lower right.

Figure 8. Cross-sectional fracture network, cluster analysis results, and fracture intensities. For Figures $8 \mathrm{~A}$ through $8 \mathrm{~F}$, the horizontal scale is the same (see scale bar below $8 \mathrm{E}$ and 8F). Fractures that cross multiple bed-centered scanlines are shown with bold lines. Layer thicknesses are not shown on these diagrams. A. Graphical representation of the fracture network documented in the 9 limestone layers shown in Figure 8A. Fractures shown in this figure are the same fractures used to produce the stereonets shown in Figure 7B. Vertical extent of fractures is not indicated on this diagram. Shaded gray regions indicate regions where fracture intensities are above $20 \mathrm{~m}^{-1}$. B. Diagram displaying fractures from set $F_{1}$. Vertical extent of fractures is indicated, with bedbound fractures abutting bed contacts and fractures that cross into beds above and/or below are shown with lines that cross bed contacts. $C_{v}$ data for each bed are shown to the right of the diagram. C. Diagram displaying fractures from set $F_{2}$. Symbols and $C_{v}$ data are the same as described for Figure 8B. D. Diagram displaying fractures from set $F_{3}$. Symbols and $C_{v}$ data are the same as those used in Figure 8B. E. Diagram displaying fractures from set $F_{4}$. Symbols and $C_{v}$ data are the same as those used in Figure $8 \mathrm{~B}$. F. Diagram displaying fractures in orientations other than those of the 4 fracture sets. Symbols are the same as those used in Figure 8B. G. Graph displaying relationship between bed thickness and fracture intensity for the four fracture sets. H. Graph displaying the relationship between bed thickness and $S / T_{f}$ for the 4 fracture sets. Symbols are the same as those used in $8 \mathrm{G}$. 
1093

1094

Figure 9. Cumulative aperture, fracture intensity, and percent extension graphs for the crosssectional fracture network. Note that beds $1-4$ have scanline lengths shorter than beds $5-9$. Bed-specific profiles start and end at the first and last fractures along each mid-bed scanline. A. Cumulative aperture profiles for $F_{1}$ fractures, graphed by bed. B. Cumulative aperture profiles for $F_{2}$ fractures, graphed by bed. One large-width fracture from bed 4 is not shown on this graph (see text for discussion). C. Cumulative aperture profiles for $F_{3}$ fractures, graphed by bed. Two large-width fractures from bed 6 are not shown on this graph (see text for discussion). D. Cumulative aperture profiles for $F_{4}$ fractures, graphed by bed. E. Cumulative apertures for each fracture set. Note that the cumulative apertures shown include apertures for all fractures in all beds, so the total cumulative apertures displayed far exceed the true cumulative aperture across the outcrop. Note that Beds $1-4$ exposure scanlines do not extend beyond $4.27 \mathrm{~m}$ (for beds 1 and 2) or $4.40 \mathrm{~m}$ (for beds 3 and 4). F. Cumulative aperture profiles, by bed, for fractures of all orientations. G. Fracture intensity versus cumulative aperture graphs for all beds, graphed by set. Graphed symbols include both bed (color) and fracture set (shape). H. Bed-thickness versus percent extension (\%e) graph for the four fracture sets.

Figure 10. Graphics displaying information about vertical persistence for the four fracture sets and for fractures at orientations different from those sets. A. Percent of fractures in each pair of beds that breach the contacts between those beds, graphed by fracture set. B. Percent of fractures that are bedbound (not crossing bedding contacts above or below the bed), graphed by fracture set. See Table 2 for more information. 
Figure 1.
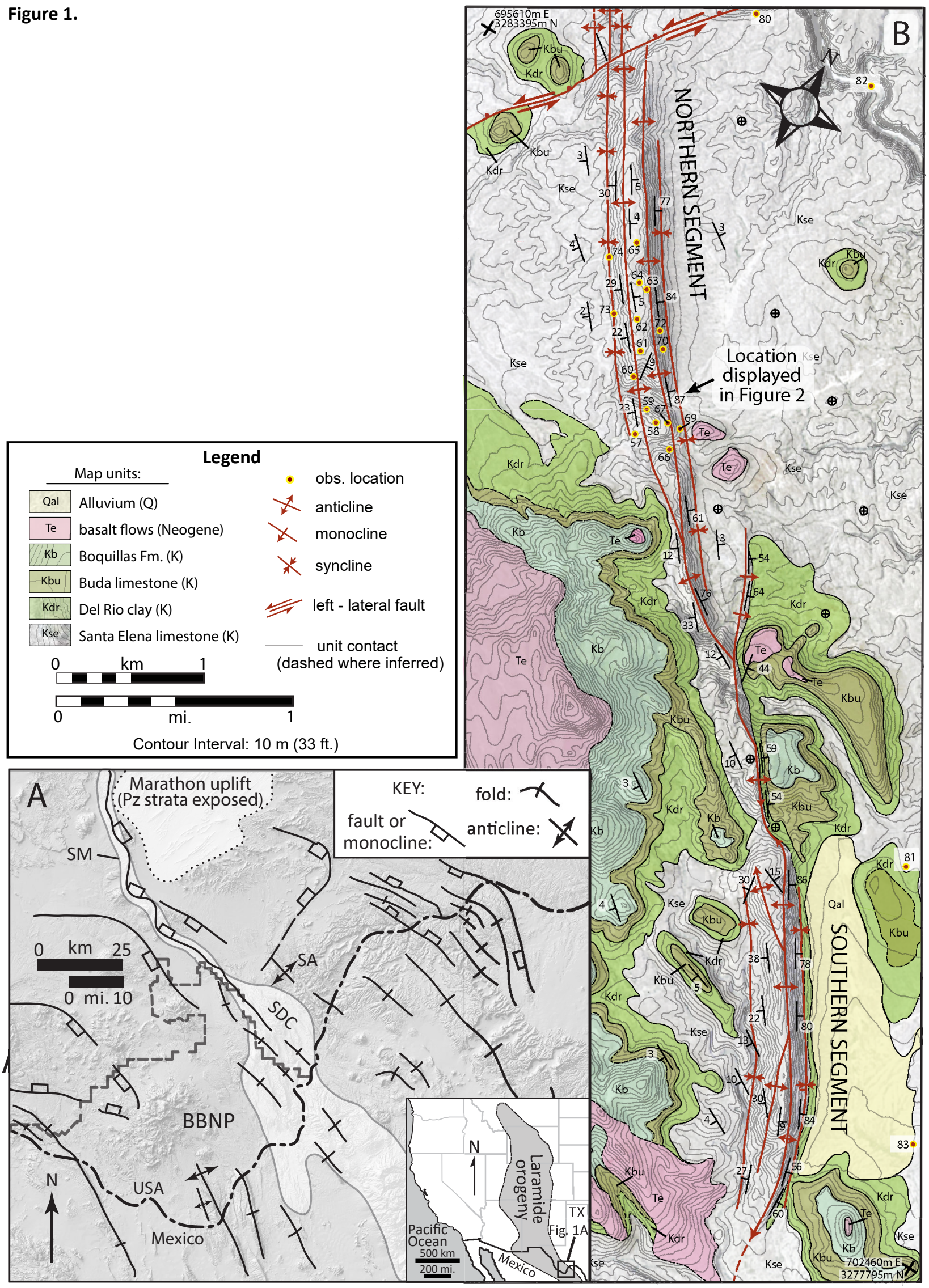

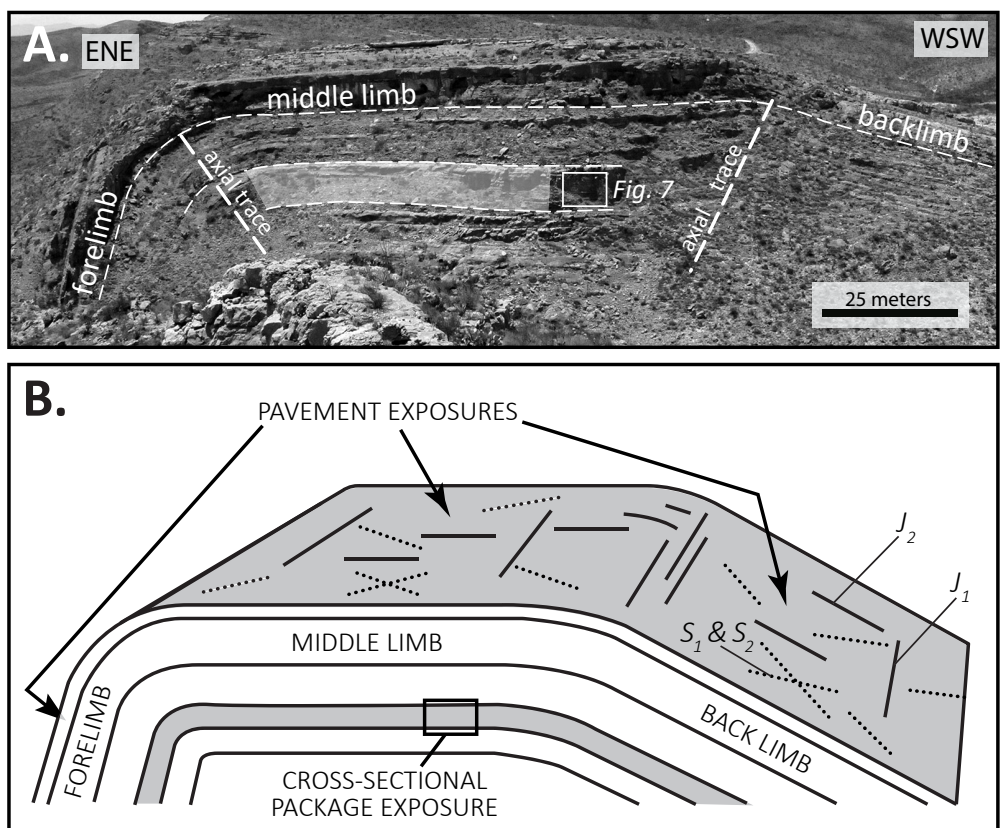

Figure 2. 


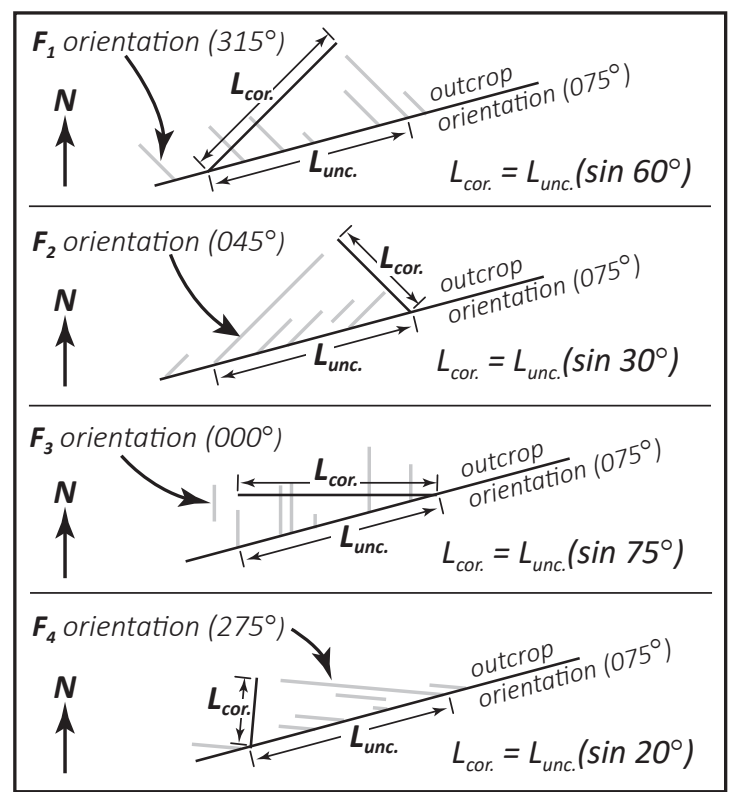

Figure 3. 


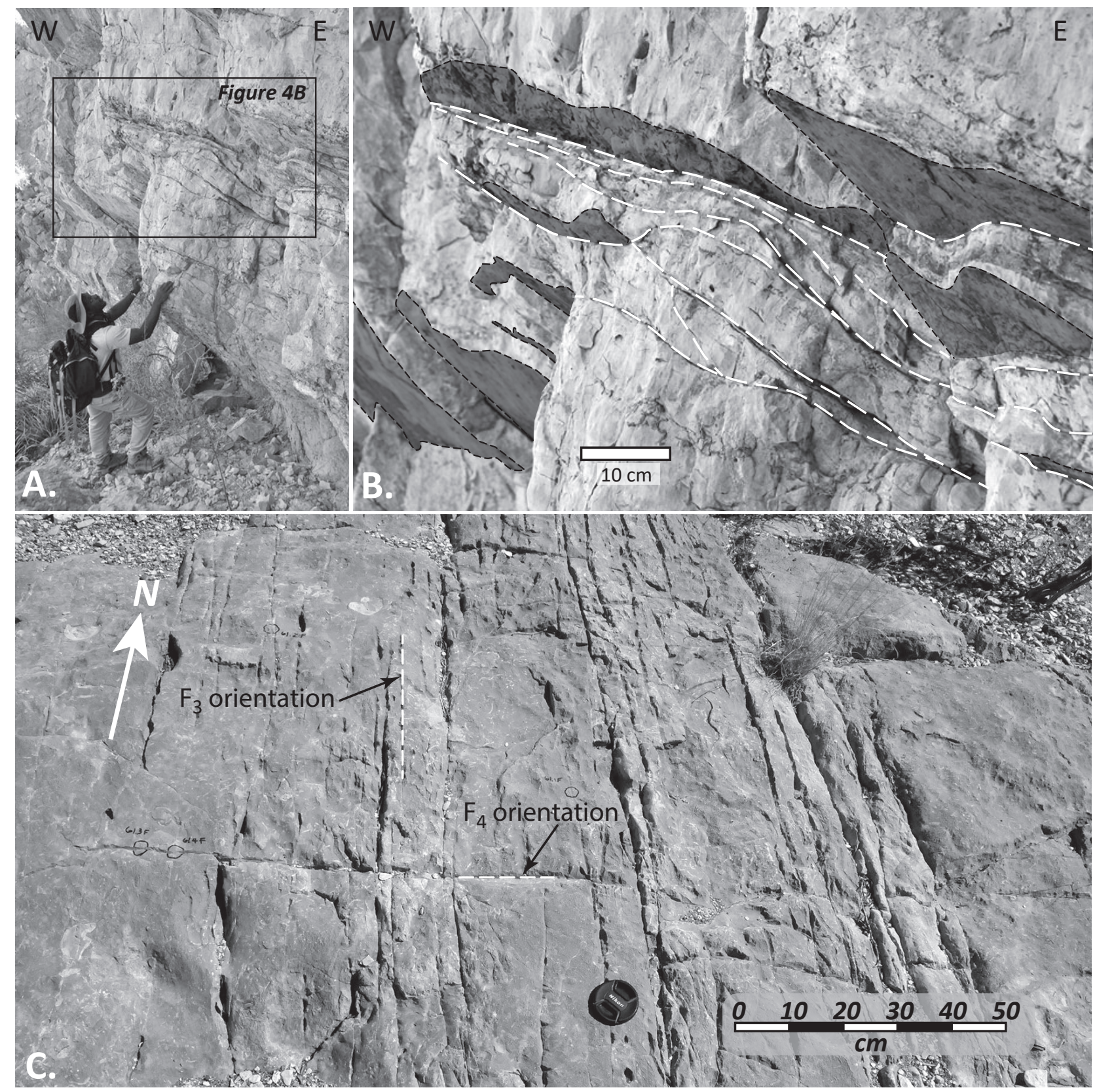

Figure 4. 


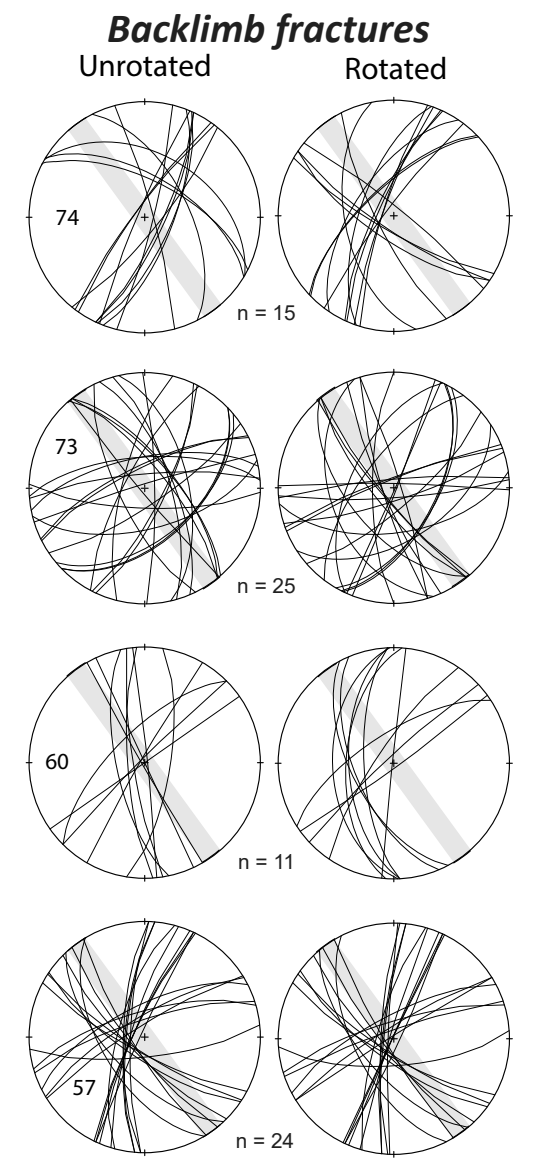

Middle limb fractures
Unrotated
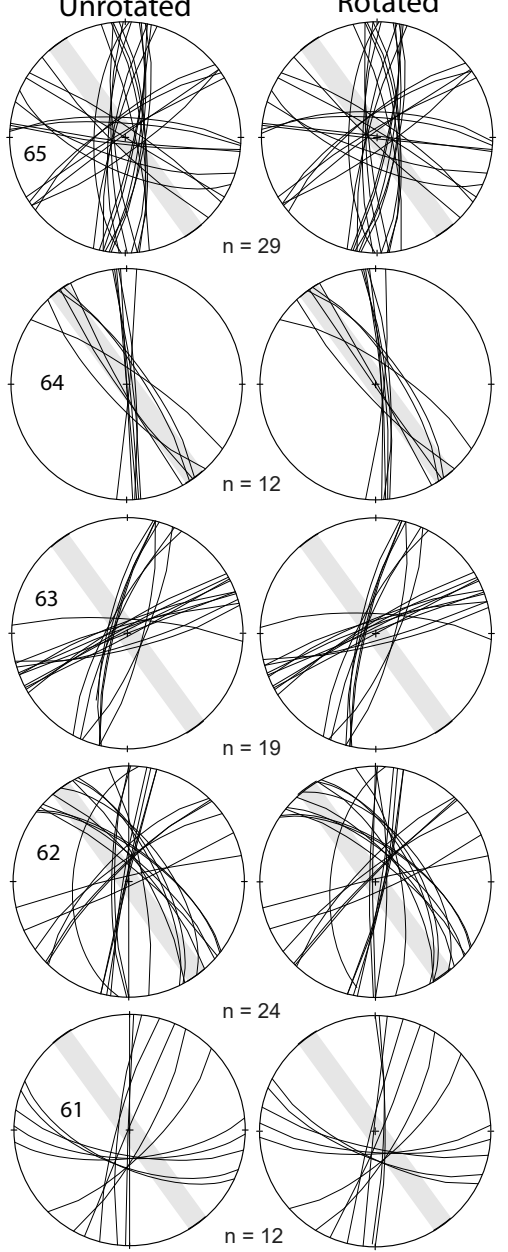

Forelimb fractures

Unrotated
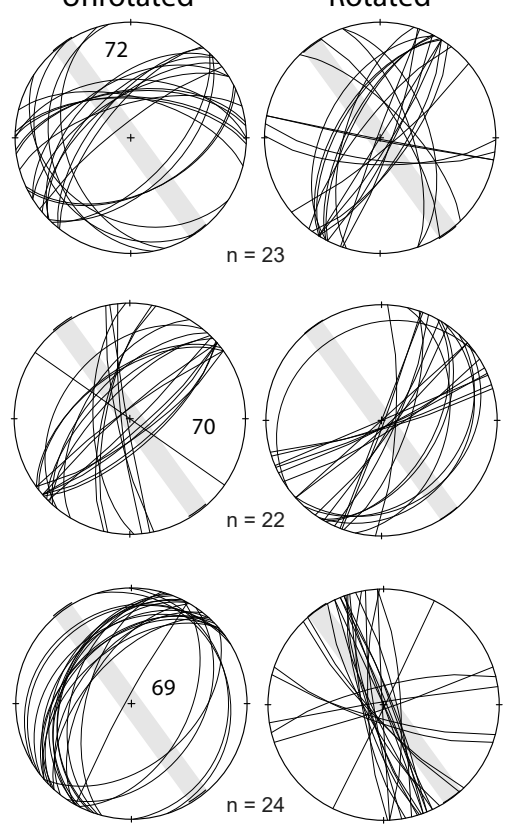

To NE of anticline
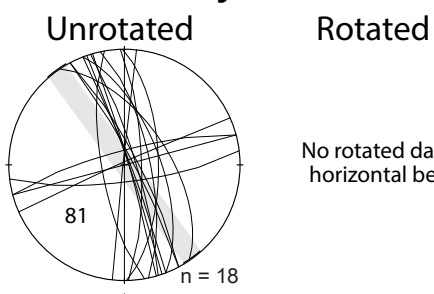

No rotated data: horizontal bed
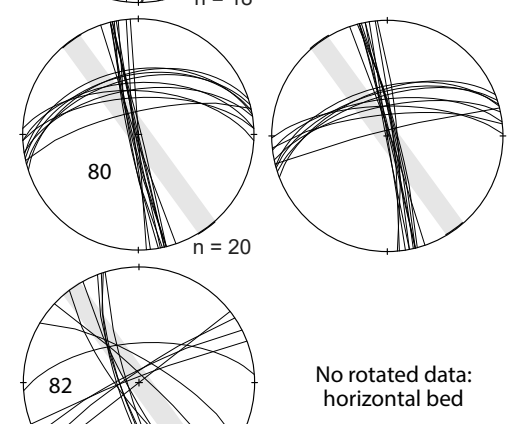

horizontal bed

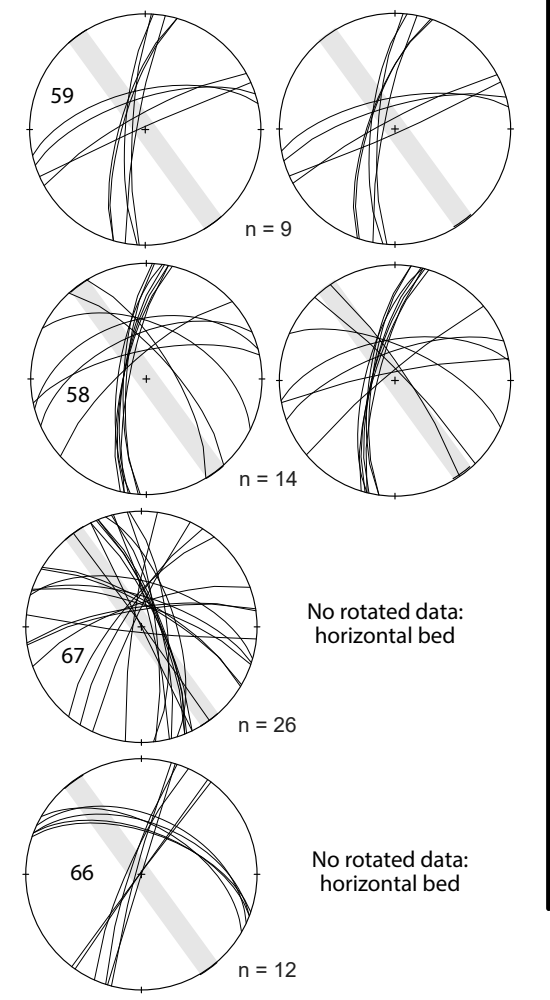

No rotated data: horizontal bed

No rotated data:

horizontal bed

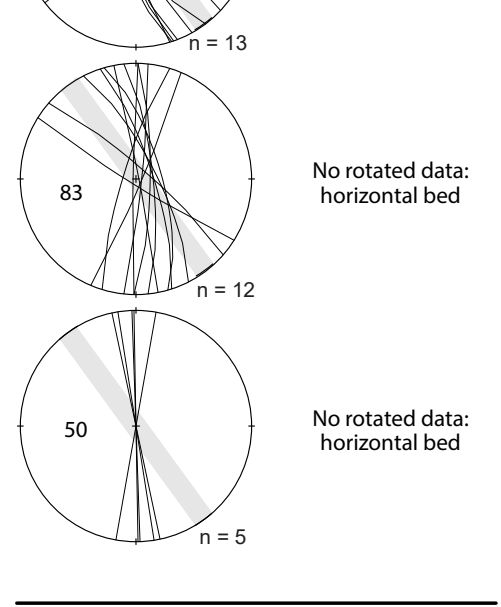

Fold fracture Sets

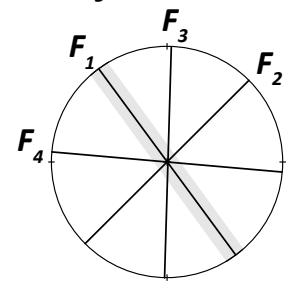

Figure 5. 


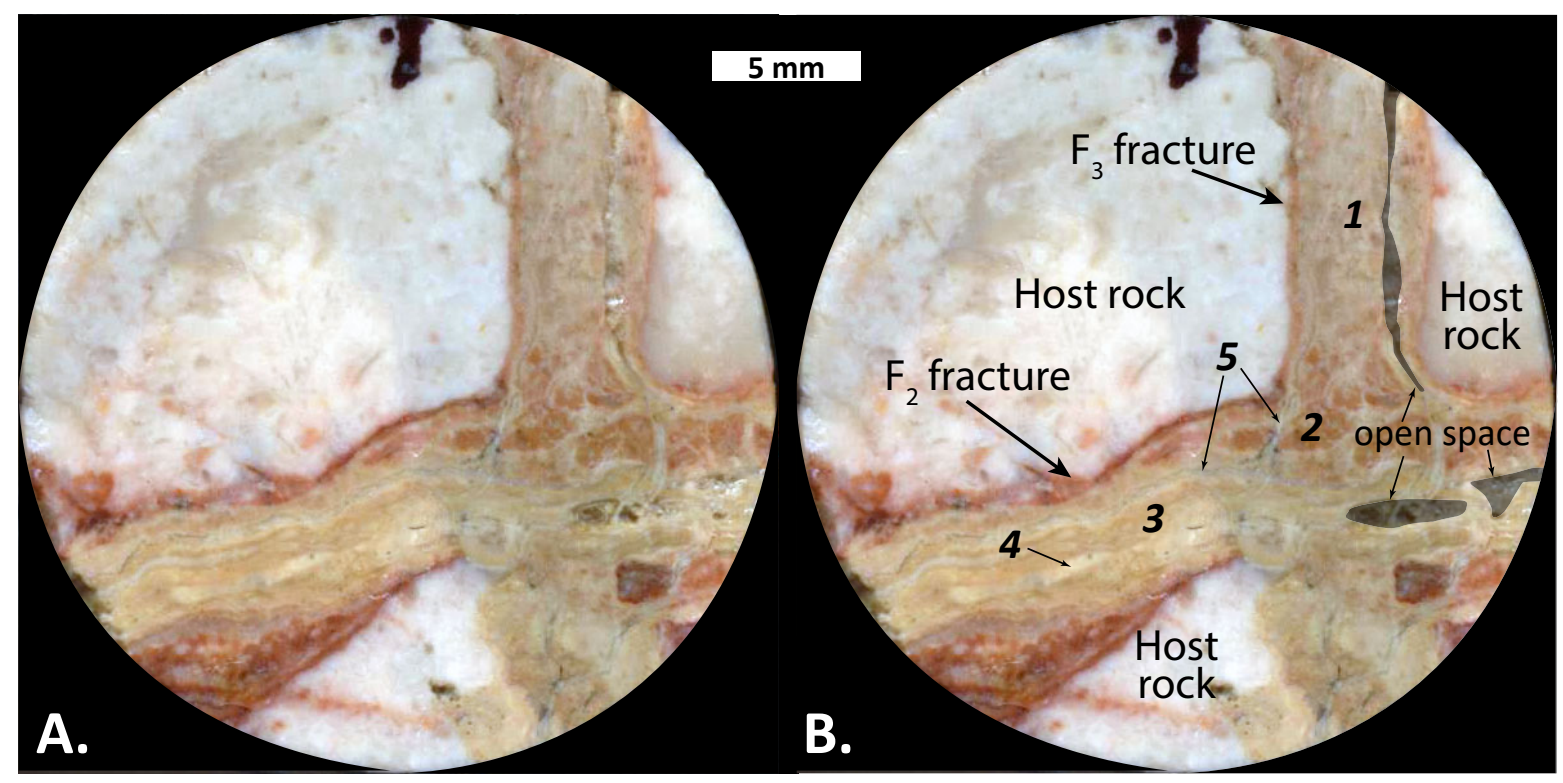

Figure 6. 


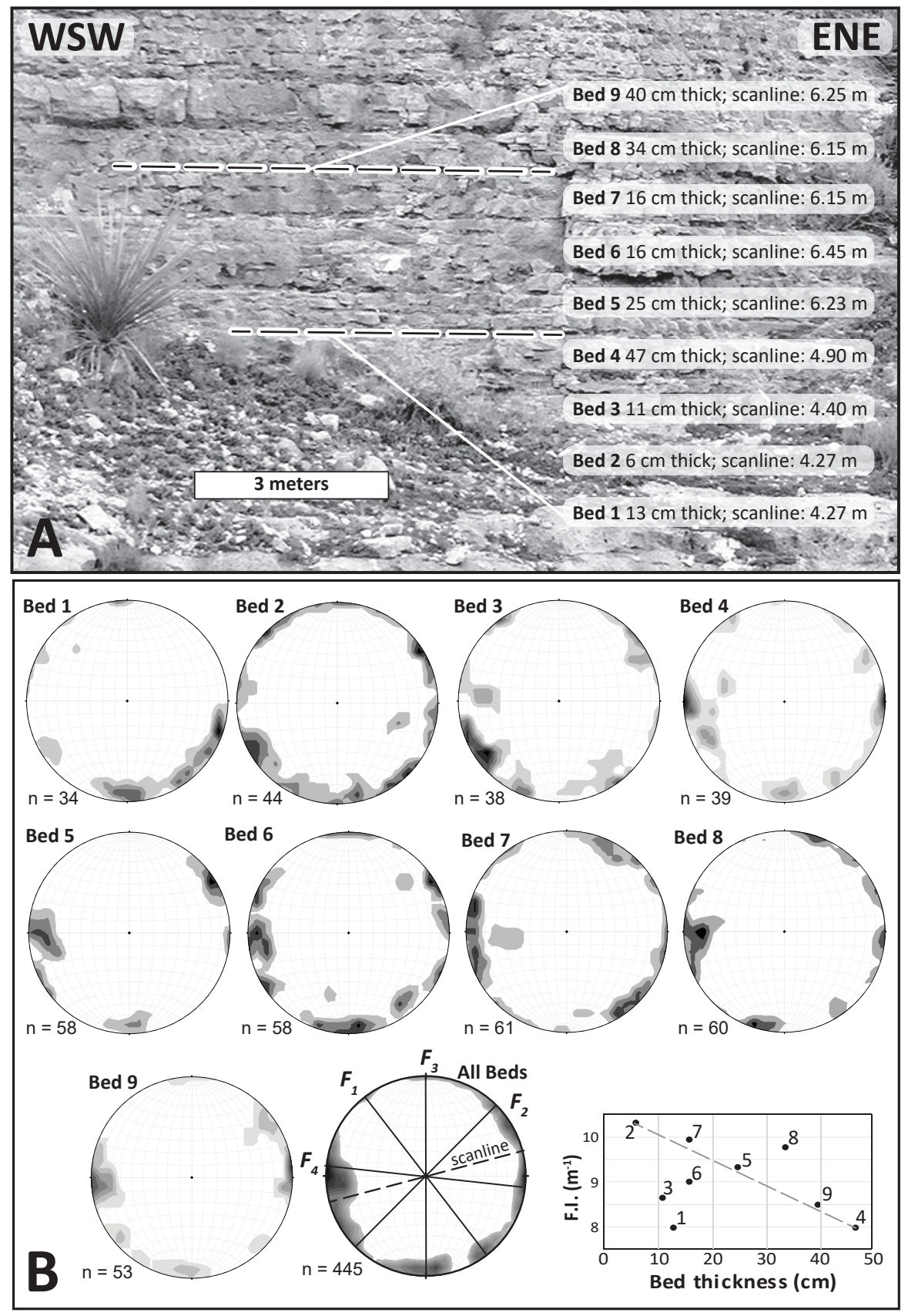

Figure 7. 


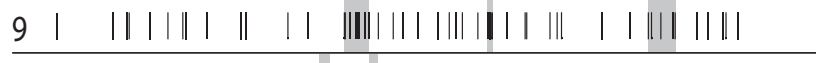

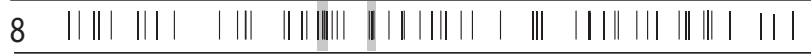

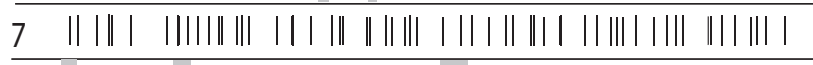

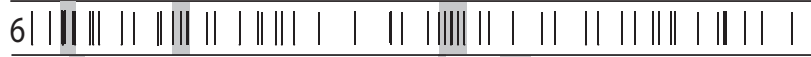

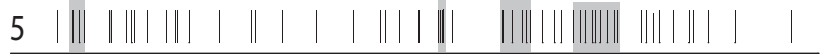

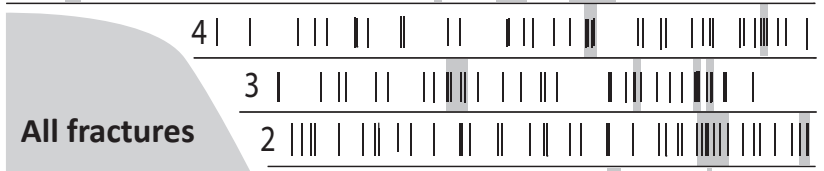
A. $\quad n=4451||||||||||||||\|\|||||||||||$
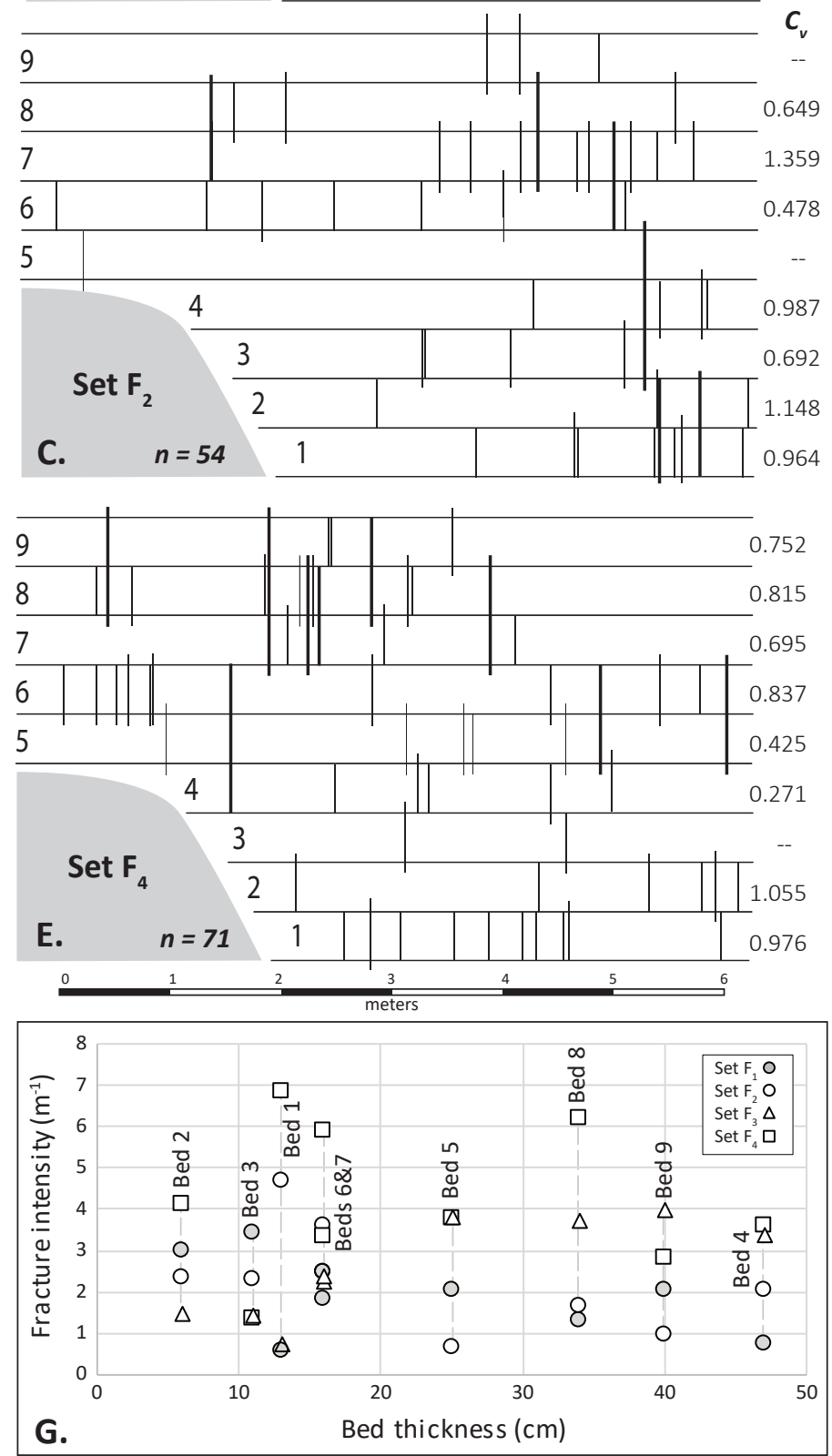

Figure 8.

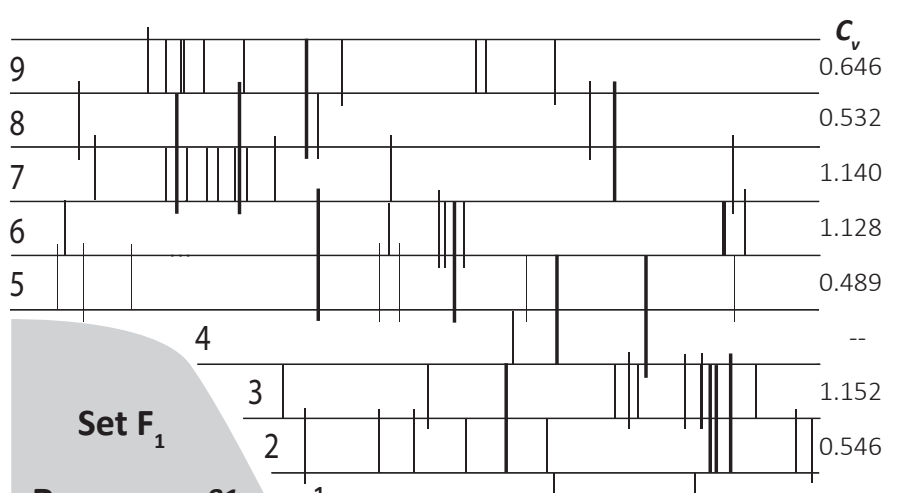

B. $n=81 \quad 1$
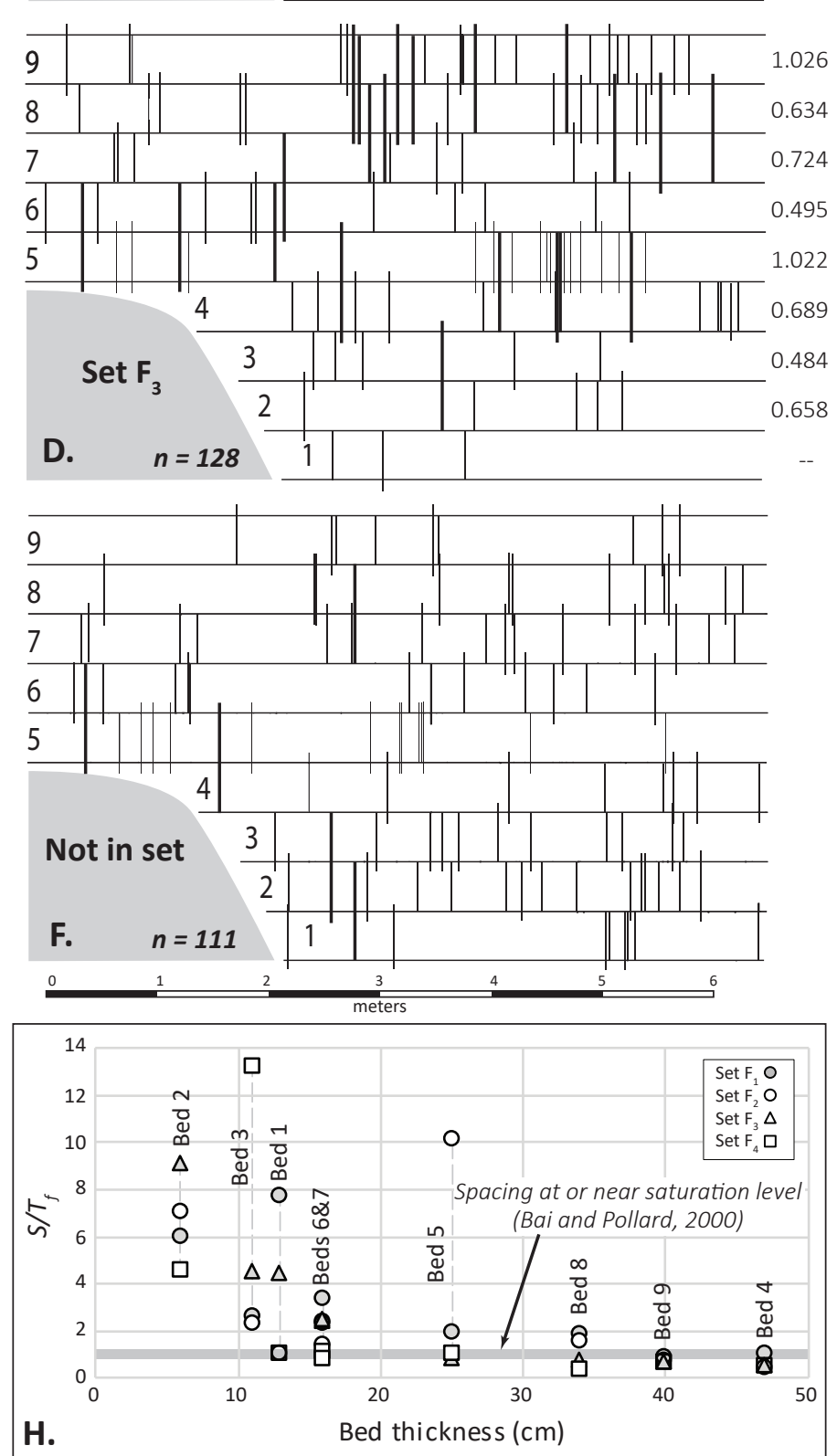

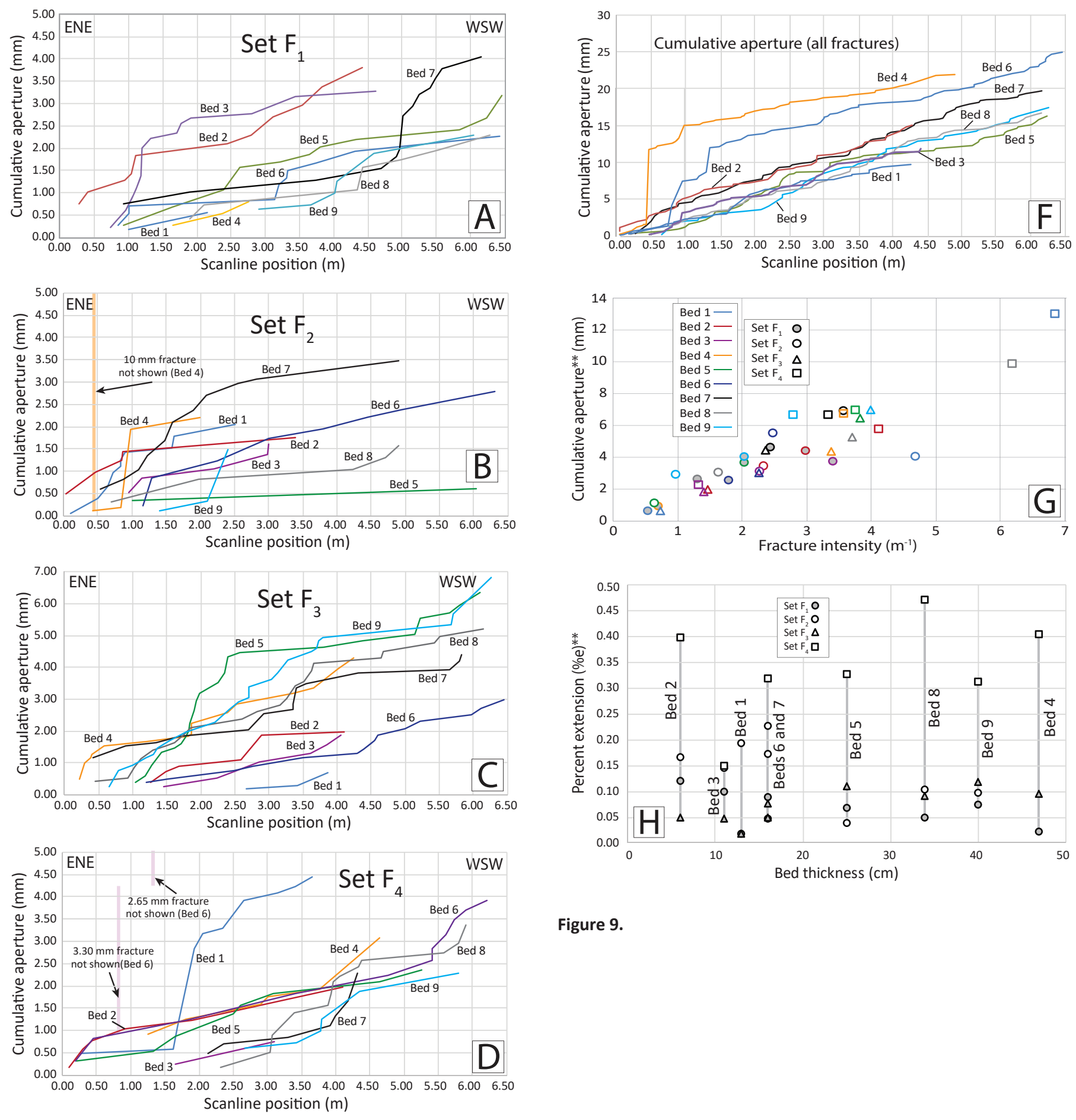

Figure 9.

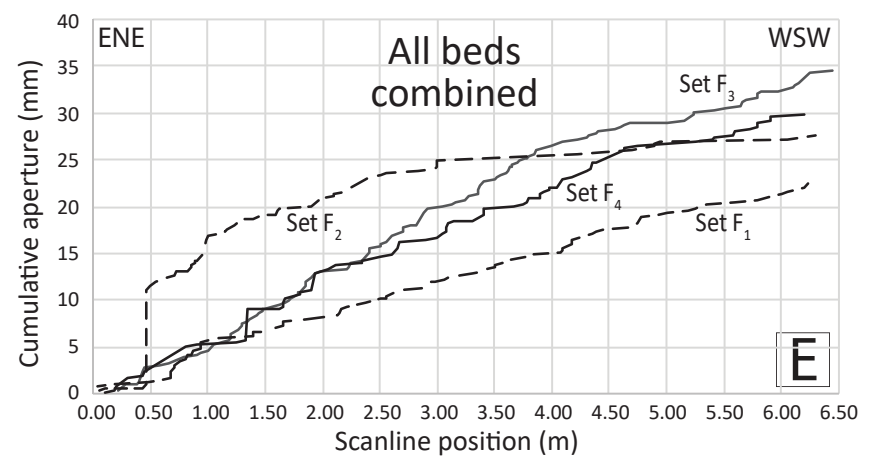




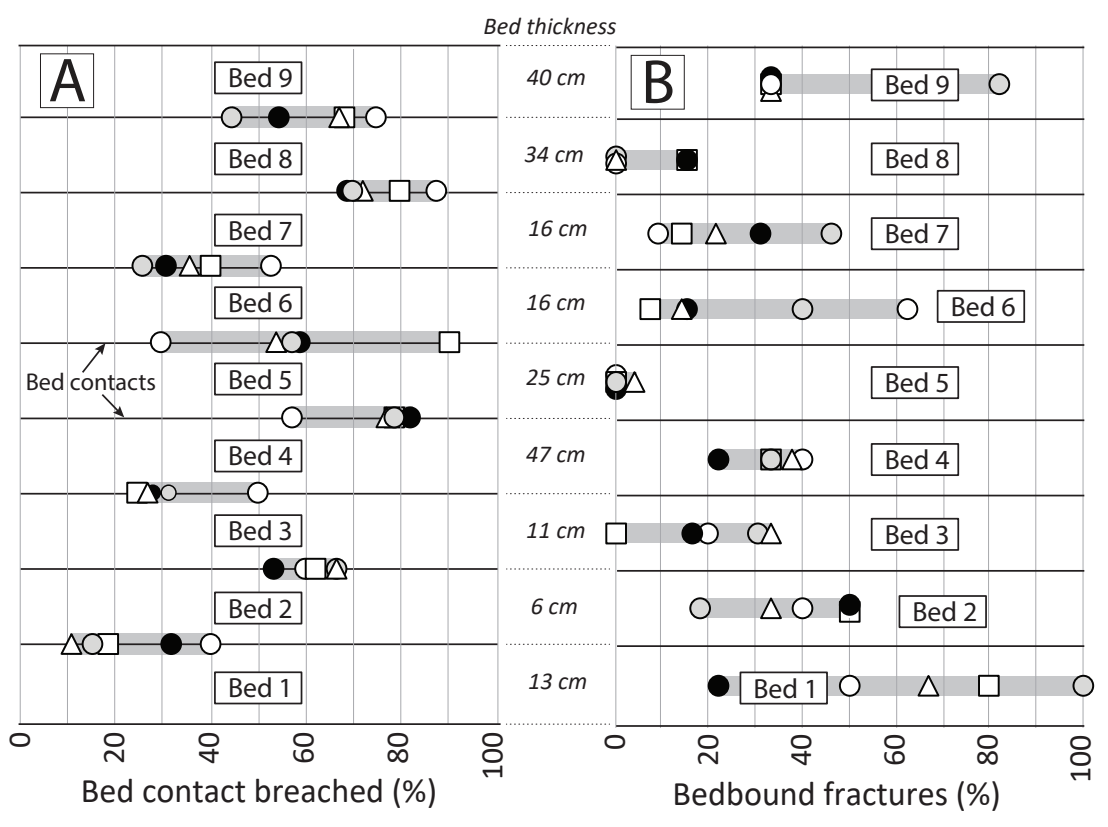

Fractures: Set $\mathrm{F}_{1} \mathrm{O}$ Set $\mathrm{F}_{2} \mathrm{O}$ Set $\mathrm{F}_{3} \square \quad$ Set $\mathrm{F}_{4} \Delta$ No Set $\bullet$

Figure 10. 
Table 1. Cross-sectional fracture data.

\begin{tabular}{|c|c|c|c|c|c|c|c|c|c|c|c|c|c|}
\hline Bed & Set & \# fract. & $\begin{array}{c}\% \text { of } \\
\text { total } \\
\text { fract. }{ }^{*}\end{array}$ & $\begin{array}{l}\text { F.I.** } \\
\left(m^{-1}\right)\end{array}$ & $\begin{array}{l}\text { ave. spacing** } \\
\text { (m) }\end{array}$ & $\begin{array}{l}\text { spacing std. } \\
\text { dev. }^{* *}(\mathrm{~m})\end{array}$ & $\begin{array}{c}\text { Spacing } \\
\mathrm{C}_{\mathrm{v}}\end{array}$ & $S / T_{f}$ & $\begin{array}{c}\text { ave. } \\
\text { aperture } \\
(\mathrm{mm})\end{array}$ & $\begin{array}{l}\text { aper. std. } \\
\text { dev. }(\mathrm{mm})\end{array}$ & $\begin{array}{l}\text { Cum. } \\
\text { Aper.** } \\
(\mathrm{mm})\end{array}$ & $\%$ e & Fracture $\%$ by set \\
\hline \multirow{6}{*}{ 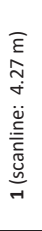 } & F1 & 2 & 6 & 0.54 & 1.005 & -- & -- & 7.7 & 0.27 & 0.08 & 0.63 & 0.02 & \\
\hline & F2 & 10 & 29 & 4.68 & 0.134 & 0.129 & 0.964 & 1.0 & 0.21 & 0.10 & 4.11 & 0.19 & \\
\hline & F3 & 3 & 9 & 0.73 & 0.580 & -- & -- & 4.5 & 0.23 & 0.15 & 0.72 & 0.02 & \\
\hline & F4 & 10 & 29 & 6.85 & 0.130 & 0.126 & 0.976 & 1.0 & 0.45 & 0.49 & 13.06 & 0.89 & \\
\hline & not in set & 9 & 26 & 2.11 & 0.528 & 0.435 & - & - & 0.22 & 0.13 & - & - & \\
\hline & All fractures & 34 & & 7.96 & 0.126 & 0.072 & - & - & 0.29 & 0.29 & - & - & \\
\hline \multirow{6}{*}{ 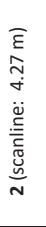 } & F1 & 11 & 25 & 2.98 & 0.359 & 0.196 & 0.546 & 6.0 & 0.35 & 0.16 & 4.42 & 0.12 & \\
\hline & F2 & 5 & 11 & 2.34 & 0.419 & 0.481 & 1.148 & 7.0 & 0.35 & 0.14 & 3.54 & 0.17 & \\
\hline & F3 & 6 & 14 & 1.46 & 0.549 & 0.361 & 0.658 & 9.2 & 0.33 & 0.23 & 2.06 & 0.05 & \\
\hline & F4 & 6 & 14 & 4.11 & 0.273 & 0.288 & 1.055 & 4.6 & 0.33 & 0.22 & 5.79 & 0.40 & \\
\hline & not in set & 16 & 36 & 3.75 & 0.247 & 0.108 & - & - & 0.32 & 0.21 & - & - & \\
\hline & All fractures & 44 & - & 10.30 & 0.097 & 0.048 & - & - & 0.33 & 0.19 & - & - & \\
\hline \multirow{6}{*}{ 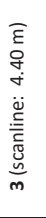 } & F1 & 13 & 34 & 3.41 & 0.281 & 0.324 & 1.152 & 2.6 & 0.25 & 0.15 & 3.78 & 0.10 & \\
\hline & F2 & 5 & 13 & 2.27 & 0.255 & 0.176 & 0.692 & 2.3 & 0.32 & 0.12 & 3.18 & 0.14 & \\
\hline & F3 & 6 & 16 & 1.41 & 0.500 & 0.243 & 0.484 & 4.5 & 0.32 & 0.09 & 1.96 & 0.05 & \\
\hline & F4 & 2 & 5 & 1.33 & 1.450 & -- & -- & 13.2 & 0.38 & 0.17 & 2.24 & 0.15 & \\
\hline & not in set & 12 & 32 & 2.73 & 0.335 & 0.135 & - & - & 0.35 & 0.18 & - & - & \\
\hline & All fractures & 38 & - & 8.64 & 0.116 & 0.079 & - & - & 0.31 & 0.15 & - & - & \\
\hline \multirow{6}{*}{ 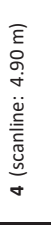 } & F1 & 3 & 8 & 0.71 & 0.476 & -- & -- & 1.0 & 0.27 & 0.00 & 0.92 & 0.02 & \\
\hline & F2 & 5 & 13 & 2.04 & 0.196 & 0.194 & 0.987 & 0.4 & 2.46 & 4.27 & 24.57 & 1.00 & \\
\hline & F3 & 16 & 41 & 3.38 & 0.258 & 0.178 & 0.689 & 0.5 & 0.27 & 0.13 & 4.46 & 0.09 & \\
\hline & F4 & 6 & 15 & 3.57 & 0.231 & 0.063 & 0.271 & 0.5 & 0.39 & 0.38 & 6.78 & 0.40 & \\
\hline & not in set & 9 & 23 & 1.84 & 0.606 & 0.28 & - & - & 0.24 & 0.14 & - & - & \\
\hline & All fractures & 39 & - & 7.96 & 0.126 & 0.060 & - & - & 0.56 & 1.58 & - & - & \\
\hline \multirow{6}{*}{ 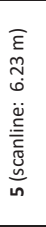 } & F1 & 11 & 19 & 2.04 & 0.481 & 0.235 & 0.489 & 1.9 & 0.29 & 0.14 & 3.68 & 0.07 & \\
\hline & F2 & 2 & 3 & 0.64 & 2.525 & -- & -- & 10.1 & 0.30 & 0.05 & 1.19 & 0.04 & \\
\hline & F3 & 23 & 40 & 3.82 & 0.222 & 0.227 & 1.022 & 0.9 & 0.28 & 0.12 & 6.57 & 0.11 & \\
\hline & F4 & 8 & 14 & 3.76 & 0.247 & 0.105 & 0.425 & 1.0 & 0.30 & 0.09 & 6.98 & 0.33 & \\
\hline & not in set & 14 & 24 & 2.25 & 0.377 & 0.380 & - & - & 0.26 & 0.09 & - & - & \\
\hline & All fractures & 58 & - & 9.31 & 0.107 & 0.075 & - & - & 0.28 & 0.11 & - & - & \\
\hline \multirow{6}{*}{ 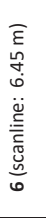 } & F1 & 10 & 17 & 1.79 & 0.54 & 0.609 & 1.128 & 3.4 & 0.23 & 0.07 & 2.61 & 0.05 & \\
\hline & F2 & 8 & 14 & 2.48 & 0.366 & 0.175 & 0.478 & 2.3 & 0.35 & 0.16 & 5.58 & 0.17 & \\
\hline & F3 & 14 & 24 & 2.25 & 0.390 & 0.193 & 0.495 & 2.4 & 0.21 & 0.08 & 3.09 & 0.05 & \\
\hline & F4 & 13 & 22 & 5.88 & 0.171 & 0.143 & 0.837 & 1.1 & 0.76 & 1.00 & 28.85 & 1.31 & \\
\hline & not in set & 13 & 22 & 2.02 & 0.436 & 0.313 & - & - & 0.54 & 0.84 & - & - & \\
\hline & All fractures & 58 & - & 8.99 & 0.111 & 0.061 & - & - & 0.43 & 0.64 & - & - & \\
\hline \multirow{6}{*}{ 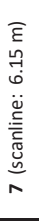 } & F1 & 13 & 21 & 2.44 & 0.380 & 0.433 & 1.14 & 2.4 & 0.31 & 0.20 & 4.67 & 0.09 & \\
\hline & F2 & 11 & 18 & 3.58 & 0.218 & 0.296 & 1.359 & 1.4 & 0.32 & 0.13 & 6.97 & 0.23 & \\
\hline & F3 & 14 & 23 & 2.36 & 0.401 & 0.290 & 0.724 & 2.5 & 0.32 & 0.28 & 4.56 & 0.08 & \\
\hline & F4 & 7 & 11 & 3.33 & 0.124 & 0.086 & 0.695 & 0.8 & 0.33 & 0.17 & 6.69 & 0.32 & \\
\hline & not in set & 16 & 26 & 2.60 & 0.392 & 0.194 & - & - & 0.34 & 0.24 & - & - & \\
\hline & All fractures & 61 & - & 9.92 & 0.101 & 0.042 & - & - & 0.32 & 0.21 & - & - & \\
\hline \multirow{6}{*}{ 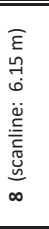 } & F1 & 7 & 12 & 1.31 & 0.635 & 0.338 & 0.532 & 1.9 & 0.33 & 0.11 & 2.63 & 0.05 & \\
\hline & F2 & 5 & 8 & 1.63 & 0.525 & 0.341 & 0.649 & 1.5 & 0.32 & 0.11 & 3.15 & 0.10 & \\
\hline & F3 & 22 & 37 & 3.70 & 0.262 & 0.166 & 0.634 & 0.8 & 0.24 & 0.08 & 5.38 & 0.09 & \\
\hline & F4 & 13 & 22 & 6.19 & 0.102 & 0.083 & 0.815 & 0.3 & 0.26 & 0.12 & 9.87 & 0.47 & 3 \\
\hline & not in set & 13 & 22 & 2.11 & 0.478 & 0.481 & - & - & 0.32 & 0.15 & - & - & \\
\hline & All fractures & 60 & - & 9.76 & 0.103 & 0.058 & - & - & 0.28 & 0.11 & - & - & \\
\hline \multirow{6}{*}{ 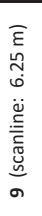 } & F1 & 11 & 21 & 2.03 & 0.290 & 0.187 & 0.646 & 0.9 & 0.32 & 0.10 & 4.03 & 0.07 & \\
\hline & F2 & 3 & 6 & 0.96 & 0.250 & -- & -- & 0.7 & 0.50 & 0.56 & 3.01 & 0.10 & - \\
\hline & F3 & 24 & 45 & 3.98 & 0.235 & 0.241 & 1.026 & 0.7 & 0.28 & 0.21 & 7.07 & 0.12 & \\
\hline & F4 & 6 & 11 & 2.80 & 0.214 & 0.161 & 0.752 & 0.6 & 0.38 & 0.21 & 6.67 & 0.31 & \\
\hline & not in set & 9 & 17 & 1.44 & 0.444 & 0.334 & - & - & 0.36 & 0.16 & - & - & \\
\hline & All fractures & 53 & - & 8.48 & 0.118 & 0.075 & - & - & 0.33 & 0.21 & - & - & \\
\hline
\end{tabular}

*may not total $100 \%$ due to rounding

**value corrected (Terzaghi, 1965) to account for set orientation relative to scanline; "All fractures" assumes a scanline value = to outcrop scanline length 
Table 2. Multi-bed fracture data

\begin{tabular}{|c|c|c|c|c|}
\hline Set & 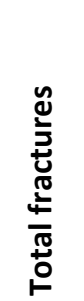 & 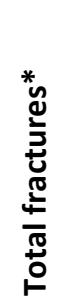 & 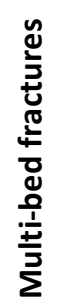 & 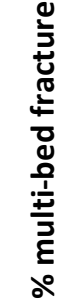 \\
\hline$F_{1}$ & 81 & 69 & 12 & 17.4 \\
\hline$F_{2}$ & 54 & 47 & 6 & 12.8 \\
\hline$F_{3}$ & 71 & 60 & 9 & 15.0 \\
\hline $\mathbf{F}_{4}$ & 128 & 107 & 21 & 19.6 \\
\hline No Set & 111 & 106 & 5 & 4.7 \\
\hline
\end{tabular}

*revised to avoid counting multi-bed

fractures more than once 